Inflation Targeting, Exchange Rate and Financial Globalization 


\section{GATE Groupe d'Analyse et de Théorie Économique Lyon-St Étienne}

93, chemin des Mouilles 69130 Ecully - France

Tel. +33 (0)4 72866060

Fax $+33(0) 472866090$

6, rue Basse des Rives 42023 Saint-Etienne cedex 02 - France

Tel. +33 (0)4 77421960

Fax. $+33(0) 477421950$

Messagerie électronique / Email : gate@gate.cnrs.fr

Téléchargement / Download : http://www.gate.cnrs.fr - Publications / Working Papers 


\title{
Inflation Targeting, Exchange Rate and Financial Globalization
}

\author{
Muhammad Naveed Tahir
}

\author{
Université de Lyon, Lyon, F-69003, France; Université Lyon 2, Lyon, F-69007, France; \\ CNRS, GATE Lyon St Etienne, Ecully, F-69130, France \\ tahir@gate.cnrs.fr
}

November 3, 2011

\begin{abstract}
In this paper we investigate the impact of financial globalization on the behaviour of inflation targeting emerging market economies with respect to exchange rate - do central banks respond to exchange rate movements or not. We use quarterly data for six emerging market inflation targeting economies from the date of their inflation targeting adoption to 2009 Q4. The study uses small open economy new Keynesian model à la Gali and Monacelli (2005), and employs multi-equation GMM technique to investigate the relationship. We find that the response of central bank to the exchange rate in case of Brazil, Chile, Mexico and Thailand is statistically significant while insignificant for Korea and Czech Republic. Theoretically, it should not be so as even under flexible inflation targeting central bank responds to inflation deviation and output gap; we think that the peculiar characteristics of emerging markets, like fear of floating, weak financial system and low level of central bank credibility make exchange rate important for these economies.
\end{abstract}

JEL Classification: E52, F41

Keywords: Inflation Targeting; Exchange Rate; Emerging Markets

Acknowledgements: I gratefully acknowledge the help and support of Aurélien Eyquem. I would also like to thank Safdar Ullah Khan and the participants at the GATE seminar, Workshop of Ecole Doctorale of University Lyon, 2011 and $15^{\text {th }}$ International Conference on Macroeconomic Analysis and International Finance, Crete, Greece, 2011. All remaining errors are my own. 


\section{Introduction:}

The world has witnessed an increase in capital movement in the last two decades among the countries on the one hand and an increment in the number of countries who adopted inflation targeting on the other hand. Among the inflation targeting adopters there are advanced countries like New Zealand, Sweden and UK who are relatively less concerned about the exchange rate movements due to their peculiar economic structure, but there are also many emerging market economies, which are more concerned about exchange rate. The reason of assigning more importance to exchange rate by emerging markets is typically the fear of floating well documented in Calvo and Reinhart (2002). Secondly, the liberalization of capital account by the emerging market economies has made the capital movements more volatile leading to volatility in exchange rates. Thirdly, when the capital inflows come in these countries, especially the hot money, it can put an upward pressure on exchange rate. This phenomenon has recently reignited a debate that should central bank respond to exchange rate or not.

However, on the other hand, according to Svensson (1999) under the IT regime a high degree of transparency is required. Therefore, economic agents should be certain that central bank is targeting only inflation or exchange rate also. We think that if this is not the case, it may lead to time inconsistency problem well documented by Kydland and Prescott (1977). Similarly, another study by Mishkin and Schimdt-Hebbel (2001), says that a focus on limiting exchange rate movements runs the risk of transforming the exchange rate into a nominal anchor that takes precedence over the inflation target. Theoretically speaking, under inflation targeting the central bank has been assigned with exclusive objective of price stability then there is less room for discussion about the reaction of monetary policy toward exchange rates but this is not the case in practice. However, it is interesting to note that in most of the IT countries the central bank has dual objective i.e. price stability and financial stability. Also one might argue that regulatory framework is the tool to achieve financial stability. We do not deny the role of prudent regulations but we think that a prudent monetary policy can also contribute in this regard. Interestingly, in our sample all the central banks have been empowered with the mandate of ensuring not only price stability but also financial stability.

Furthermore, there is the well known "impossible trinity", according to which high capital mobility can co-exist with independent monetary policy only when exchange rate is free float, otherwise, the monetary policy becomes subservient to exchange rate policy. So theoretically, a country cannot have all three goals simultaneously. As for the last decade, emerging markets have increasingly been adopting inflation targeting. On the other hand, in the environment of free capital mobility the role of exchange rate in stabilizing the economy cannot be underestimated, due to economic structures of emerging market economies. So in this backdrop, the motivation of the study comes from the fear of 
floating and the theory of inflation targeting. The purpose of this study is to investigate empirically whether the central banks of the sample countries respond to exchange rate or not.

The rest of the document is structured as follows. Section 2 provides a brief overview of the literature. In section 3 we present model and theoretical explanation of the model. Section 4 describes the methodology and the data. Section 5 presents some stylized facts whereas section 6 explains the empirical results and the final section provides some concluding remarks.

\section{Literature Review:}

The paper by Calvo and Reinhart (2000) finds that the countries that say they allow their exchange rate to float mostly do not - there seems to be an epidemic case of "fear of floating". Similarly, Cavoli (2009) concludes that fear of floating is justified in open developing economies. Another paper with the same line of arguments is by Ball (2000). According to this paper the exchange rate should also be included in the reaction function of the central bank. However, whether it should be on the right side of the Taylor Rule or the left side is an empirical question. In the former case it is extended Taylor rule and the latter is Monetary Condition Index (MCI). Thus the paper introduces MCI. The question is why exchange rate is important? There is variety of channels through which exchange rates impact the economy, illustrated in the paper by Svensson (1999). The interest rate differential impacts the exchange rate and the expected future exchange rate through the interest rate parity condition. And due to existence of sticky prices, the nominal exchange rate affects the real exchange rate. The real exchange rate will affect the relative price between domestic and foreign goods, which consequently, have an impact on both domestic and foreign demands for foreign goods and thus contribute to the aggregate demand channel for the transmission of monetary policy. Then there is a direct channel, which brings imported inflation in the case of depreciation. Typically the impact of direct channel is quicker relative to the aggregate demand channel. Besides these, another channel through which exchange rate affects the economy is the domestic currency prices of imported intermediate inputs. Due to depreciation the prices of the inputs increase and this leads to increase in the cost of production and subsequently to domestic Inflation, this is called cost channel. Furthermore, if the wages are indexed to the CPI the depreciation will cause an increase in nominal wages. This is the real side of the economy, then there is financial side, according to Calvo and Reinhart (2000) and Kaminsky and Reinhart (1999) if the liabilities of the banking sector and/or the government are dollar denominated the value of foreign debt in domestic currency goes up in the wake of depreciation and this makes the smooth functioning of these institutions quite difficult and even, in some cases, may lead to banking sector crises. According to another study, Aghion, Bacchetta and Banerjee, (2000), if nominal prices are rigid currency depreciation causes an increase in the foreign currency debt repayment obligations of the firms leading to a decline in their profits; this reduces firms borrowing capacity and 
subsequently investment and output in a credit constrained economy, which leads to depreciation spiral. Another channel, which recently has been identified by Lane and Milesi-Ferretti (2004), emphasizes that larger gross crossholdings of foreign assets and liabilities means that the valuation channel of exchange rate has grown in importance, relative to the traditional trade balance channel. All these effects bring the exchange rate in central stage in an open economy, and in this globalized world economies are becoming more and more

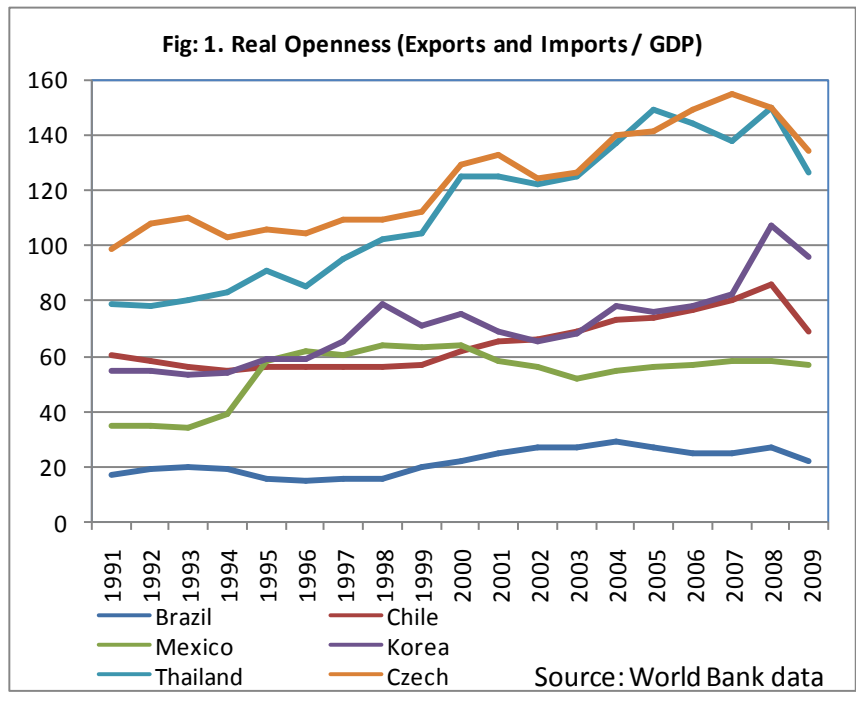
open, (see figure 1).

The literature about the response of central bank, specifically, to exchange rate movements can be divided into two strands; (1) the empirical and (2) the theoretical or calibrated. In the former category we have Edwards (2006), the study concludes that, among other results, there is some evidence that IT countries with history of high inflation takes into account exchange rate movements while conducting monetary policy. Similarly, Aizenman et al. (2008) concludes that inflation targeting emerging market economies follow mixed strategy. This study also uses single equation like Edwards (2006). In another study by Hebbel and Tapia (2002) the conclusion is that, although exchange rate pass-through has declined, the Bank of Chile still responds to exchange rate misalignments. Osawa (2006) concludes that Philippines, Thailand and Korea do not react to exchange rate movements. Mohanty and Klau (2004) use GMM to estimate Taylor rule for 13 emerging and developing economies and conclude that central banks in most of these countries respond to exchange rate movements.

In the second category we have De Paoli (2006), which uses calibration and impulse response. The study takes exchange rate into account, arguing that welfare is affected by exchange rate volatility, so exchange rate cannot be ignored. The paper concludes that domestic inflation targeting is only preferable when the economy is closed. The study uses two country dynamic general equilibrium model. Similarly Parrado (2004) uses simple dynamic new Keynesian model and concludes that if there is a real shock, flexible exchange rates dominates managed exchange rates. Secondly, domestic inflation appears to outperform CPI and flexible inflation target is preferable to strict inflation target. Cavoli (2009) uses small open economy model for Philippines, Thailand, Korea and Indonesia and concludes that fear of floating still exists for developing economies. According to Gali and Monacelli (2005) domestic inflation targeting policy, in terms of contribution to welfare losses, is a better policy 
relative to CPI target or Pegged exchange rate. Gali and Monacelli is a special case where elasticity of substitution between goods is 1 . The result does not hold for more general environments.

The studies mentioned above use either single equation Taylor rule or rely on calibration. Our study is different as it uses a small open economy new Keynesian model but most of the parameters are estimated. So this study has a consistent estimation of a small new Keynesian model instead of single equation Taylor rule or relying heavily on parameterization (calibration). The contribution of the study is that it bridges the gap between the two strands - empirical and calibrated studies. The methodology we use is multi-equation GMM that takes very much care of the simultaneity inherent to monetary policy studies due to transmission lag and interdependence among the variables in the model. So the study answers a very relevant question - due to financial globalization - that emerging market inflation targeting central banks respond to exchange rate movements or not using small open economy new Keynesian model estimated with multi-equation GMM that is robust to simultaneity bias.

Our sample includes six countries; Brazil, Chile, Mexico, Korea, Thailand and Czech Republic. The reasons behind the selection of these countries are (i) they are inflation targeters (ii) they have been under fixed or managed floating exchange rate regime before adoption of IT (iii) the sample represents Latin America, Asia and Central Europe. Coming to the characteristics of sample countries, if we look at recent history, before adoption of IT, the situation is very interesting. According to Calvo et al . (1995), Chile provides an example of Purchasing Power Parity (PPP) rule, the study further says that in July 1985, an exchange rate band was established whose central parity was adjusted at daily intervals according to the schedule based on the inflation rate during the previous month minus the estimated world inflation rate and this rule was intact until January 1992. According to Carstens and Werner (1999), Mexico experienced a forced transition to the floating regime. The study says that current account deficit; illiquidity of the Mexican government and the looming banking crises paved the path for balance of payment and financial crises. These developments compelled the central bank to let the peso float. Brazil was under a crawling pegged system from 1994 to 1998. After the late1998 currency crises, Brazil adopted floating exchange rate system. On the other hand, in South East Asia, too, the situation was more or less similar to the above mentioned Latin American countries. According to Osawa (2006), Korea was under the managed floating regime until October 1997, however, it became independently floater after November 1997, whereas Thailand was under fixed exchange rate regime till June 1997, and then moved to managed floating. In the Eastern Europe, Czech Republic was under the fixed exchange rate regime against Deutsche Mark (DM) when the Czech Republic was struck by currency crisis in 1997. According to a study by Creel and Levasseur (2004), the root cause of the crisis was excessive credit to the firms by the state-owned banks and on the other hand, the firms did not go for restructuring and lost competitiveness. Consequently, the 
external imbalances engulfed the economy. The Central Bank increased the interest rate in vain to defend the regime and ultimately, abandoned the fixed exchange rate regime in favour of managed float against DM. And few months later in December 1997, Czech Republic adopted inflation targeting regime.

We now contrast the level of financial globalization of these countries with respect to their movements toward flexible exchange rate regime. Brazil adopted independent floating in 1999, Chile also in 1999, although it is interesting to note that Chile adopted inflation targeting in 1991, Mexico adopted independent floating exchange rate at the end of 1994. According to Dooley et al. (2002), before the crisis in 1997 Korea was characterized by a tightly managed exchange rate regime. Similarly, according to Osawa (2006), Korea was under the managed floating regime until October 1997, whereas Thailand was under fixed exchange rate regime until June 1997, and then moved to managed floating.

As depicted above, the countries that constitute our sample have been associated with the fixed exchange rate regime before adopting inflation targeting. This also makes a convincing reason to explore the response of the central banks to exchange rate movements, as the exchange rate might still be haunting the economic agents in these countries. We turn to our model in the next section.

\section{The Model:}

We use a small open economy New Keynesian Model that closely follows Gali and Monacelli (2005). The model consists of households, firms and a central bank. So our econometric model for the inflation targeting framework for open economies includes three basic equations: an aggregate demand or dynamic IS type equation, the Phillips Curve representing the supply side and our third equation is an interest rate rule, a modified Taylor rul. The assumptions of the model are: (i) the prices of the goods and inputs are set by the private economic agents instead of Walrasian auctioneer seeking to clear all the markets at once that is that is firms face monopolistic competition; (ii) there exist nominal rigidities, that is, firms are subject to some constraints on the frequency with which they can adjust the prices of the goods and services they sell. Alternatively, existence of menu cost has been assumed. Needless to say, that these nominal rigidities induce short run non-neutrality of monetary policy. In the long run, however, monetary policy is no more non-neutral; (iii) uncovered interest rate parity and purchasing power parity hold.

$$
\mathrm{y}_{\mathrm{t}}=\mathrm{E}_{\mathrm{t}} \mathrm{y}_{\mathrm{t}+1}-1 / \sigma_{\alpha}\left(\mathrm{i}_{\mathrm{t}}-\mathrm{E}_{\mathrm{t}}\left(\pi_{\mathrm{h}, \mathrm{t}+1}\right)\right)+\varepsilon_{\mathrm{t}}^{\mathrm{y}}
$$

$\mathrm{y}_{\mathrm{t}}$ is output gap measured as natural log deviation of Gross Domestic Product (GDP) from the potential value of GDP measured with HP filter, $\sigma_{\alpha}$ is a structural parameters that depends upon some other 
structural parameters, that we will explain shortly, whereas Fisherian ex-ante equation $\left(i_{t}-E_{t}\left(\pi_{t+1}\right)\right)$ has been used to calculate the real interest rate and $\varepsilon^{y}$ is the stochastic error term.

Equation (1) which represents the demand side of the economy is an open economy expectational, forward-looking dynamic IS curve where current output gap is a positive function of one period ahead expected output gap, and a negative function of the real interest rate. Indeed as it is commonly argued that an increase in the real interest rate will depress the level of investment on one hand, and increase the level of saving on the other hand, thus having downward impact on output level through investment and consumption, while the opposite holds true for the decline in real interest rate (Chadha and Dimsdale, 1999). However, the story is not as smooth as it looks, for example, Bilbiie (2008) emphasize the role of degree of asset market participation in the determination of slope of IS curve. The study is of the view that moderate participation in financial markets strengthen the role of monetary policy while low enough participation can cause an inversion of the IS curve. This can lead to blatant opposition to the 'Keynesian' conventional wisdom. This also in fact depends upon the relative strength of the substitution effect, which works toward more saving at higher interest rate, and the income effect which works toward less saving at higher interest rate. So the substitution effect and income effect are not only concerned with the asset market participation but also with the income distribution in the society. ${ }^{1}$ Similarly, in deflationary episodes the potency of monetary policy becomes questionable as despite very low interest rates economy does not grow as it would in normal days. This is the situation where zero bound interest rate becomes a constraint on the monetary authorities and they resort to tools like fiscal stimulus and /or quantitative easing. The other factor that explains negative relationship between real interest rate and output is investment. It would not be out of place to mention here that in developing countries political instability also matters though it is almost always there in developed economies. Besides all that, recent research emphasizes that it is not the level of real rate as such rather the 'natural' or 'equilibrium' value of the real rate that matters for the output gap (Neiss and Nelson, 2001; Woodford, 2003). However, the academic questions arise there with what certainty one can calculate the 'natural' or 'equilibrium' value of the interest rate and does it remains constant for a reasonable period of time to implement and see the results.

An important parameter of equation 1 is

$$
\sigma_{\alpha=\sigma /(1-\alpha)+\alpha \omega}
$$

where $\sigma$ is the coefficient of relative risk aversion and under the assumption of usual time-separable utility function $1 / \sigma$ is the elasticity of intertemporal substitution (EIS) between consumption in any

\footnotetext{
${ }^{1}$ Furthermore, the position of households that they are net creditors or debtors is also important in this regard. However, we assume that substitution effect dominates so consumption decreases in first period and increases in second.
} 
two periods. So EIS measures the extent to which an increase in the interest rate induces consumers to substitute future consumption for present consumption. According to Favero (2005) the value of EIS below 1 means that income effect dominates whereas if it is greater than 1 the substitution effect dominates. The other parameter is $\alpha$, it measures the degree of openness. The third parameter is the function of some structural parameters as;

$$
\omega=\sigma \gamma+(1-\alpha)(\sigma \eta-1)
$$

whereas $\gamma$ measures the substitutability between goods produced in different countries. It captures the taste preference of the economy and $\eta$ measures the substitutability between domestic and foreign goods from the view point of domestic consumers. According to Gali and Monacelli (2005) if $\omega$ is greater than 1 contractionary effect of real appreciation dominates and vice versa.

The last term $\varepsilon^{\mathrm{y}}{ }_{\mathrm{t}}$ is an unanticipated demand shock (like public spending, or preference disturbance) or expectation error. It is assumed to be white-noise and temporary in nature.

Now we move to the supply side of the economy that is captured through the small open economy New Keynesian Phillips Curve (NKPC). This equation is essential to evaluate monetary policy, as it traces the price setting behaviour of the firms and therefore the characteristics of inflation dynamics. We start with the closed economy NKPC;

$$
\pi_{\mathrm{h}, \mathrm{t}}=\beta \mathrm{E}_{\mathrm{t}} \pi_{\mathrm{h}, \mathrm{t}+1}+\lambda \mathrm{mc}_{\mathrm{t}}+\varepsilon_{\mathrm{t}}^{\pi}
$$

$\beta$ is the subjective discount factor and it can take the value $0<\beta<1$. In most of the studies its value has been assumed 0.99 , which means a riskless annual return around 4 percent in the steady state.

Equation (2) represents the supply side of a closed economy. It is a New Keynesian Phillips Curve, which can be derived from various price setting behaviour. It is also a measure of excess demand, assuming that there is no stagflation. It is a forward-looking expectation-augmented Phillips curve where current domestic inflation $\left(\pi_{\mathrm{h}, \mathrm{t}}\right)$, measured here as GDP deflator, depends upon expectations of economic agents about future domestic inflation and a second term $\mathrm{mc}_{\mathrm{t}}$ which denotes real marginal cost. So it is evident domestic inflation is positive function of real marginal cost. The simple text book argument that as real marginal cost increases, so does the cost of production and subsequently inflation. The coefficient attached with $\mathrm{mc}_{\mathrm{t}}$ is $\lambda$. It is the slope of the Phillips curve and is of first order importance, as it tells us how flat or steep a Phillips curve is. This parameter is a function of some structural parameters as;

$$
\lambda=(1-\theta)(1-\theta \beta) / \theta
$$

where $\theta$ is the probability that a firm keeps its price unchanged. So it is related to the degree of price stickiness à la Calvo (1983). Conversely, (1- $\theta$ ) is the probability that a firm is allowed to adjust the 
price. While firm changing their prices, they need to take into account future inflation, as they may not be able to adjust their prices for several periods. The higher the value of $\theta$, the lesser the pressure on inflation as firms change price less frequently. The value of $\theta$ depends upon many factors like, competition among firms, economic situation, historical level of inflation, etc. Furthermore, the value of $\theta$ can also be influenced by the market structure and the issues like complementarity among the firms. Besides these factors, it also depends upon the communication strategy and credibility of the central bank. Consequently, $\lambda$ captures the speed of price adjustment, the larger $\lambda$ implies that a larger proportion of firms adjust their prices each period, keeping the aggregation problems aside.

Finally, in equation (2), $\varepsilon^{\pi}{ }_{\mathrm{t}}$ is a cost push shock, for example, an adverse supply shock of oil. In new Keynesian literature this causes the trade-off between inflation and output variance.

However, the NKPC presented in equation (2) is a closed-economy version. As we are dealing with open economy, we relate it to the open economy as the study of Gali and Monacelli (2005) does. As according to Gali and Monacelli (2005), in a small open economy the Consumer Price Inflation (CPI), $\pi_{\mathrm{t}}$, is the combination of domestic price inflation $\pi_{\mathrm{h}, \mathrm{t}}$ and of changes in the terms of trade $\Delta \mathrm{s}_{\mathrm{t}}$. So the relationship can be described as following

$$
\pi_{\mathrm{t}}=\pi_{\mathrm{h}, \mathrm{t}}+\alpha \Delta \mathrm{s}_{\mathrm{t}}
$$

so the difference between two measures of inflation comes through the percent change in the terms of trade whereas $\alpha$ is the index of trade openness. We can relate the terms of trade with the real effective exchange rate as follows;

$$
\mathrm{s}_{\mathrm{t}}=\mathrm{q}_{\mathrm{t}} /(1-\alpha)
$$

where $\mathrm{q}_{\mathrm{t}}$ is the real effective exchange rate. Hence;

$$
\pi_{\mathrm{t}}=\pi_{\mathrm{h}, \mathrm{t}}+\alpha /(1-\alpha) \Delta \mathrm{q}_{\mathrm{t}}
$$

Substituting the value of $\pi_{\mathrm{h}, \mathrm{t}}$ from equation (2) in equation (5) we get;

$$
\pi_{\mathrm{t}}=\beta \mathrm{E}_{\mathrm{t}} \pi_{\mathrm{h}, \mathrm{t}+1}+\lambda \mathrm{mc}_{\mathrm{t}}+\alpha /(1-\alpha) \Delta \mathrm{q}_{\mathrm{t}}+\varepsilon_{\mathrm{t}}^{\pi}
$$

Equation (6) is thus the open-economy NKPC, where foreign elements have been incorporated through the real effective exchange rate $\left(q_{t}\right)$. An increase in $q_{t}$ means a depreciation of the domestic currency in real terms. It is worth mentioning here that the study of Gali and Monacelli (2005) does not incorporate real exchange rate explicitly as our study does.

Equation (6) can also be represented in terms of output gap, following Gali and Monacelli (2005) we can relate the real marginal cost and output gap as: 


$$
\mathrm{mc}_{\mathrm{t}}=\left(\sigma_{\alpha}+\psi\right) \mathrm{y}_{\mathrm{t}}
$$

So equation (6) becomes;

$$
\pi_{\mathrm{t}}=\beta \mathrm{E}_{\mathrm{t}} \pi_{\mathrm{h}, \mathrm{t}+1}+\lambda\left(\sigma_{\alpha}+\psi\right) \mathrm{y}_{\mathrm{t}}+\alpha /(1-\alpha) \Delta \mathrm{q}_{\mathrm{t}}+\varepsilon^{\pi}{ }_{\mathrm{t}}
$$

where $\lambda(\sigma \alpha+\psi)$ is the slope of the open economy NKPC. As $\sigma \alpha$ depends upon some open economy structural parameters like degree of openness, substitutability between domestic and foreign goods so here competition with foreign firms also influences the price setting behaviour of domestic firms. In addition, $\psi$ is the elasticity of labour supply with respect to wage rate.

The equation (7) can also be presented in more compact form as:

$$
\pi_{\mathrm{t}}=\beta \mathrm{E}_{\mathrm{t}} \pi_{\mathrm{h}, \mathrm{t}+1}+\mathrm{k}_{\alpha} \mathrm{y}_{\mathrm{t}}+\alpha /(1-\alpha) \Delta \mathrm{q}_{\mathrm{t}}+\varepsilon^{\pi}{ }_{\mathrm{t}}
$$

where;

$$
\mathrm{k}_{\alpha=} \lambda\left(\sigma_{\alpha}+\psi\right)
$$

So we have derived a small open economy NKPC, where CPI inflation depends upon expected domestic future inflation, output gap and real effective exchange rate. It is a micro founded rationalexpectations Phillips curve, where firms set their price à la Calvo (1983), and where degree of trade openness also matters.

Now we move to monetary policy rule;

$$
\mathrm{i}_{\mathrm{t}}=\rho \mathrm{i}_{\mathrm{t}-1}+(1-\rho)\left[\varphi_{\pi}\left(\pi_{\mathrm{t}}-\pi^{*}\right)+\varphi_{\mathrm{y}} \mathrm{y}_{\mathrm{t}}+\varphi_{\mathrm{e}}\left(\Delta \mathrm{e}_{\mathrm{t}}\right)\right]+\varepsilon_{\mathrm{t}}^{\mathrm{i}}
$$

Equation (9) closes the model by a monetary policy rule. It is a type of Instrument Rule adopted by the central bank for an open economy, where the current nominal interest rate $\left(i_{t}\right)$ is a positive function of inflation deviation, that is, if current inflation $\left(\pi_{t}\right)$ is higher than the announced target $\left(\pi^{*}\right)-$ for target of inflation set by the central bank of the respective country, in this model we use two periods ahead inflation - the central bank will jack up the nominal interest rate and vice versa. For this the central bank will also rely on its forecast of inflation, as inflation forecast becomes its intermediate target.

Secondly, the current nominal interest rate is also a positive function of output gap, in case of positive output gap $\left(\mathrm{y}_{\mathrm{t}}\right)$ central bank will increase interest rate to slow down the overheated economy. Assuming that substitution effect is stronger than income effect and thus putting downward pressure on aggregate demand, the increase in interest rates will pay the dividends. Thirdly the nominal exchange rate $\left(e_{t}\right)$ also enters with positive sign in the equation (an increase in e is a depreciation) and this is due to imported inflation. The other possible explanation is that the central bank seeks to stop 
outflows in the backdrop of depreciation or encourage inflows, if the economy is much integrated with the world economy, especially financially.

Finally, we assume that the central banks tend to smooth interest rate changes because of parameter uncertainty, data uncertainty and because they dislike financial market volatility. Therefore, we include a smoothing term $(\rho)$ whereby the current interest rate also depends on the lagged interest rate. The equation also has $\varepsilon_{\mathrm{t}}^{\mathrm{i}}$ stochastic monetary policy shock.

Although the Taylor type reaction function is very much in use; there are other potential candidates. Batini, Harrison and Millard (2003) discuss a battery of rules. Beside the Taylor rule, their study gauges the performance of naïve MCI rule, Ball (1999), inflation-forecast-based rule (IFB) and some other variants. Their study finds that IFB, a rule that reacts to deviations of expected inflation from the target, is a good simple rule. The study further says that, an IFB rule, with or without exchange rate adjustment, appears robust to different shocks, in contrast to naïve or Ball's MCI-based rules. Furthermore, a study by Svensson (1997) goes this way "even though I believe instrument rules like the McCallum and Taylor rules are important advances in the theory of monetary policy, I consider a commitment to a target rule to be more advantageous than a commitment to an instrument rule. A target rule focuses on the essential, that is, to achieve the goal, and allows more flexibility in finding the corresponding reaction function". However, we use this Taylor-type rule due to its simplicity and we use this small scale micro founded canonical New Keynesian model because of its parsimony and tractability. Although it is without solid micro foundations like habit persistence, we think that it yet provides the stylized representation of the key aggregates in the economy and captures the essence of monetary policy transmission mechanism.

Now we turn to our two critical assumptions, i.e. uncovered interest rate parity and purchasing power parity. Equation (10) below is the uncovered interest rate parity;

$$
\mathrm{i}_{\mathrm{t}}-\mathrm{i}_{\mathrm{t}}{ }^{*}=\mathrm{E}_{\mathrm{t}}\left(\mathrm{e}_{\mathrm{t}+1}-\mathrm{e}_{\mathrm{t}}\right)
$$

which states that if the domestic nominal interest rate is above the foreign nominal interest rate there is a positive expected appreciation of the foreign currency to compensate for the lower foreign interest rate. So interest rate parity simply means that the expected returns are same on both domestic currency deposits and foreign currency deposits in the long run. It thus characterizes international asset market equilibrium.

The last equation of our model is equation (11)

$$
\left(\mathrm{e}_{\mathrm{t}}-\mathrm{e}_{\mathrm{t}-1}\right)=\pi_{\mathrm{t}}-\pi_{\mathrm{t}}^{\mathrm{f}}
$$


This equation describes how exchange rate and inflation rate are related through purchasing power parity. If the domestic price level is higher than the foreign price level the domestic currency will depreciate. Equation (10) and (11) reveal that we assume complete financial markets. After setting our model and explanation of the assumption we extensively describe the methodology in our next section.

\section{Methodology:}

As our model describes the dynamics of inflation, output gap, interest rates and exchange rates, endogeneity might be a problem. In this backdrop we use the Generalized Method of Moments (GMM) to estimate the values of the parameters. More specifically the study uses multi-equation GMM. The multi-equation GMM is considered as efficient compared to the single-equation GMM. So we distinguish our study from the ones that use only single equation GMM to estimate Taylor rule or calibrate the model. As multi-equation GMM makes joint estimation, we have "efficiency gain". The reason for efficiency gain is, the single equation ignores the information about the equation contained in other equations. We will make no assumption about the interequation (or contemporaneous) correlation between the error terms and no prior restrictions are placed on the coefficients from different equations. The advantage of this technique that on one hand it obviates the endogeneity bias or simultaneity bias and on the other hand it brings "efficiency gain".

We use lagged values of explanatory variables as instruments. Another important issue is orthogonality condition. According to Hayashi (2000), orthogonality condition for the system of equation is just a collection of orthogonality condition for individual equation. It is worth mentioning here that instrument and lag selection has always been a ticklish task. A good instrument is a predetermined variable that is correlated with the endogenous regressor but orthogonal to the error term. To the best of our knowledge, there is no hard and fast rule for lag selection. Tauchen (1986) claims that it is better to use small number of instruments set, because the confidence intervals are more reliable. For further discussion on this issue see Gallant and Tauchen (1996). However, following the standard practice in literature the instrument set consists of lagged dependent variables.

The study uses quarterly data from various sources like International Financial Statistics (IFS-IMF), Bank for International settlements (BIS) and websites of respective Central Banks. The starting date corresponds to the date of adoption of inflation targeting by the respective countries and up till the fourth quarter of year 2009 except for Thailand for which the end point is fourth quarter of year 2008 . We calculate output gap by log difference of real GDP from its detrended value. Detrending is achieved using Hodrick-Prescott filter (The smoothing parameter is set to the default of 1600 for quarterly data). To calculate the real interest rate we use the Fisherain equation. The nominal exchange rate (domestic currency per US Dollar), is taken in log difference, and an increase in $e_{t}$ means depreciation. For inflation deviation we take the difference of current inflation minus two period ahead target of inflation set by the central bank of the respective country. The inflation target has been taken 
from the website of the central bank of the respective country. The real exchange rate has been taken from the website Bank for International Settlements (BIS). We converted the monthly REER index into quarterly by taking end-period average. Interestingly, it was in line with the quarterly data of REER quoted by IFS as the REER Index for Chile was available in the IFS. Furthermore, we inversed the index to make it compatible with the explanation that an increase in an index means depreciation of domestic currency. Indeed, we would like to mention that for Chile's discount rate, the policy rate was not available since 1991 so we used lending rate up to 1993 Q1.

In the traditional time series econometrics, stationarity is critical. To check the stationarity we use Augmented Dickey Fuller (ADF) and Kwiatkowski, Phillips, Schmidt and Shin (1992). According to Verbeek (2004), in the latter test, stationarity is the null hypothesis and the existence of a unit root is the alternative. The basic idea is that a time series is decomposed into the sum of a deterministic time trend, a random walk and a stationary error term (typically not white noise). The null hypothesis (of trend stationarity) specifies that the variance of the random walk component is zero. Although we report the results of both tests, we heavily rely on KPSS test.

\section{Stylized Facts:}

In this section we well describe the stylized facts and try to have an idea about the relationship between variables. For this purpose we will use covariance matrix that indicates the direction of linear relationship between two variables, for example, if covariance between two variables is greater than zero then there is a positive relationship between two variable and vice-versa. However, one should be cautious that covariance does not tell us much about the strength of such relationship. It is pertinent to mention here that covariance is influenced by the unit of measurement. To avoid this problem we also report correlation coefficient, which uses standardized data. Furthermore, graphic relationship has also been reported to provide a visual analysis. Needless to say that these elements are reported just to have a quick overview of the relationships among variables although when they interact in model they may behave

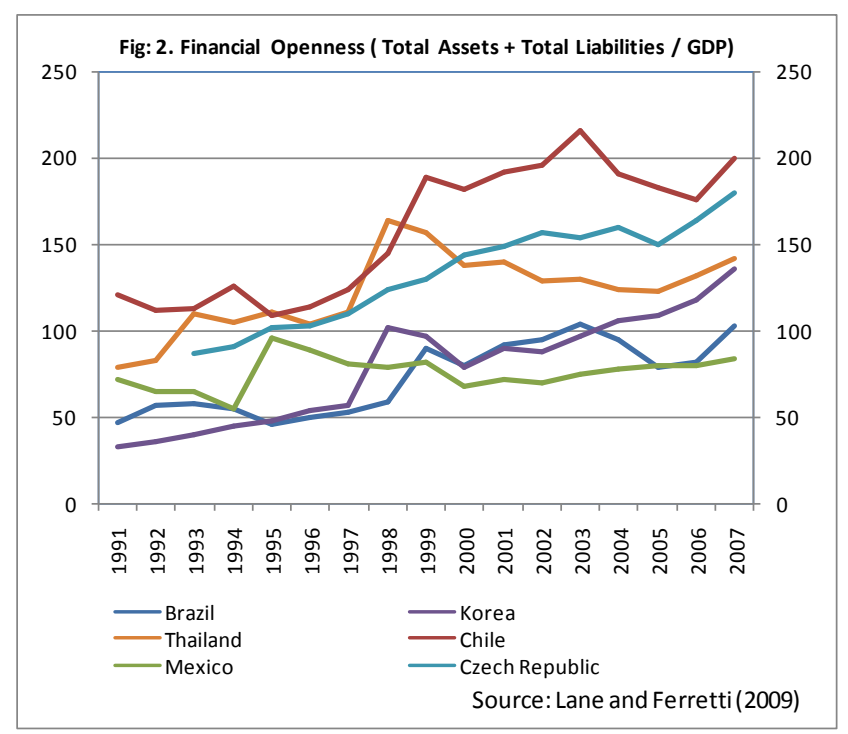
differently. See Table in Appendix. Generally speaking, the covariance and correlation are in line with the theory however, exception is there. Similarly we have also put graphic presentation in the Appendix that gives a fair idea about the relationship between output gap and inflation. The one 
question that comes to mind here is that what the evolution of financial globalization tells us about these countries. See the figure below.

It is clear from the figure that the level of financial globalization increased rapidly. Almost all the countries observed an increasing trend except Mexico. Mexico is the single country that registered a downward trend; it may be due to the policies adopted by the Mexican government or the health of the Mexican economy that could not catch the foreign inflows due to low level of investors' confidence. We cannot say definitively unless we know the policies regarding the capital account liberalization during the period under discussion. Although the data is only up to 2004 yet we tend to believe that in the recent years the trend was not reversed. However, it is worth mentioning here that government of Brazil imposed capital inflow tax in October 2009 in the wake of heavy capital inflows that were creating problems for monetary authorities in the conduct of monetary policy. Otherwise, to the best of our knowledge we do not find any country that have had adopt such a discouraging step to the inflows.

As we have earlier mentioned in our text that all the countries in our sample not only entrust their central banks the objective of price stability but also the smooth function and stability of financial sector. Due to this mandate along with the presence of relatively weak financial system the higher volatility in exchange rate also becomes a source of concern for the central banks of these countries. The mandates of these central banks have been summarized in the Table 1, below.

Table 1: Mandate of Central Banks

\begin{tabular}{|c|c|}
\hline Brazil & To endure the stability of currency's purchasing power and a solid and efficient financial system. \\
\hline Chile & $\begin{array}{l}\text { The issuance of bank notes and coins, the regulation of the amount of money in circulation } \\
\text { and credit, the regulation of financial system and capital market, faculties to preserve } \\
\text { financial system stability ... }\end{array}$ \\
\hline Mexico & $\begin{array}{l}\text { Main function is to provide currency to the domestic economy. Ensure stability of the currency's } \\
\text { purchasing power. Its other functions are to promote both the sound development of the financial } \\
\text { system and the optimal functioning of the payment system. }\end{array}$ \\
\hline Korea & $\begin{array}{l}\text { The Bank of Korea monitors the financial system and evaluates its stability.... The Bank also contributes } \\
\text { to maintaing financial stability by identifying and providing potential risk factors in the financail } \\
\text { sector to prevent them from causing financial system unrest. }\end{array}$ \\
\hline Thailand & $\begin{array}{l}\text { [Along with the MP] Bank of Thailand supervises, examines and analyzes the financial status and } \\
\text { performance, and risk management system of the financial institutions in order to promote financial } \\
\text { institutions stability }\end{array}$ \\
\hline Czech R. & $\begin{array}{l}\text { With its primary objective CNB sets monetary policy ..... It also performs supervision of the banking } \\
\text { sector, the capital market ....... As well as foreign exchange supervision. }\end{array}$ \\
\hline
\end{tabular}

This mandate, keeping in mind the studies by Calvo and Reinhart (2000) and Kaminsky and Reinhart (1999), makes it necessary for these central banks to take exchange rate into account. 


\section{Estimation and Results:}

In this section we describe the estimation results. Table 2 reports the results of the following three equations

$$
\begin{gathered}
\mathrm{y}_{\mathrm{t}}=\mathrm{E}_{\mathrm{t}} \mathrm{y}_{\mathrm{t}+1}-1 / \sigma_{\alpha}\left(\mathrm{i}_{\mathrm{t}}-\mathrm{E}_{\mathrm{t}}\left(\pi_{\mathrm{t}+1}\right)\right)+\varepsilon^{\mathrm{y}}{ }_{\mathrm{t}} \\
\pi_{\mathrm{t}}=\beta \mathrm{E}_{\mathrm{t}} \pi_{\mathrm{h}, \mathrm{t}+1}+\mathrm{k}_{\alpha} \mathrm{y}_{\mathrm{t}}+\alpha /(1-\alpha) \Delta \mathrm{q}_{\mathrm{t}}+\varepsilon^{\pi}{ }_{\mathrm{t}} \\
\mathrm{i}_{\mathrm{t}}=\rho \mathrm{i}_{\mathrm{t}-1}+(1-\rho)\left[\varphi_{\pi}\left(\pi_{\mathrm{t}}-\pi^{*}\right)+\varphi_{\mathrm{y}} \mathrm{y}_{\mathrm{t}}+\varphi_{\mathrm{e}}\left(\Delta \mathrm{e}_{\mathrm{t}}\right)\right]+\varepsilon_{\mathrm{t}}^{\mathrm{i}}
\end{gathered}
$$

The basic idea underlying our estimation strategy is to use the theoretical NK Small Open Economy model (NKSOE) to investigate the reaction of central bank toward exchange rate movements in a general equilibrium model where we can also estimate structural parameters like risk aversion, and the duration of price contracts. We would like to mention that we calibrate the time discount factor $\beta$. As it is standard in literature that the studies using quarterly data, we set $\beta=0.99$. The second parameter that we calibrate is $\alpha$. We tried to estimate it but it was not well identified. It is openness index measured as import to GDP ratio.

The overall results are encouraging and in line with our expectations. However, we also find some interesting results for coefficient of relative risk aversion. The value of risk aversion is much controversial in literature and its value has very wide range ${ }^{2}$ from 1 to 55 .

Our first coefficient is relative risk aversion. As it is evident from the Table 2 (below) that have a negative and significant relationship between output gap and real interest rate as the theory suggests. The value of the risk aversion is rather large for Brazil and Chile. As we have already mentioned the value of this parameter is much controversial in literature. The high risk aversion parameter indicates that economic agents in Brazil and Chile are more risk averse and they have strong tendency to smooth consumption relative to other countries. Moreover, the negative relationship of output gap with the real interest rate supports that substitution effect is stronger than income effect, as it is generally expected.

We might have taken risk aversion parameter from literature and circumvent the problem of its high value - that of course is not unusual - but we prefer to let the data speak. We think that this exercise brings originality in other parameters of the model so it is more representative of the economic situation.

\footnotetext{
${ }^{2}$ See Attanasio et al. (2000), Campbell (1996), Campbell et al. (2003), Chapman (2002) and Mehra and Prescott (1985).
} 
The second coefficient is slope of Phillips curve. For most of the countries we have a positive slope as it should be. It means that output gap is an important indicator in determining the current inflation. In literature the magnitude of $k_{\alpha}$ varies widely. For example, Mihailov et al. (2011) while estimate an open economy NKPC and find the minimum value for slope parameter to be 0.00 in case of Austria and the maximum to be 0.24 in case of UK.

\begin{tabular}{|c|c|c|c|c|c|c|c|}
\hline & $\sigma_{\alpha}$ & $\mathbf{k}_{\boldsymbol{\alpha}}$ & $\rho$ & $\varphi_{\pi}$ & $\varphi_{\mathrm{y}}$ & $\varphi_{\mathrm{e}}$ & $\mathbf{J}$ (Prob) \\
\hline Brazil & $-38(6.52)$ & $.071(.035)$ & $.96(.002)$ & $3.12(.27)$ & $2.42(.44)$ & $.84(.11)$ & $10.72(.97)$ \\
\hline Chile & $-24(11.10)$ & $.55(.10)$ & $.65(.08)$ & $5.20(1.38)$ & $1.00(.83)^{*}$ & $1.57(.27)$ & $15.34(.28)$ \\
\hline Mexico & $-8.35(.95)$ & $.98(.05)$ & $.92(.00)$ & $4.79(.15)$ & $1.31(.13)$ & $.14(.04)$ & $9.55(.98)$ \\
\hline Korea & $-11.34(4.86)$ & $-.06(.05)^{*}$ & $.96(.00)$ & $7.90(1.76)$ & $1.28(.14)$ & $-1.13(.23)$ & $11.33(.83)$ \\
\hline Thailand & $-1.67(.22)$ & $.41(.03)$ & $.97(.00)$ & $5.26(1.67)$ & $.69(.27)$ & $1.24(.60)$ & $9.58(.65)$ \\
\hline Czech & $-6.17(1.88)$ & $.54(.25)$ & $.93(.00)$ & $1.09(.29)$ & $.46(.08)$ & $-.17(.03)$ & $11.93(.85)$ \\
\hline
\end{tabular}

Note: The * attached to the coefficient means it is insignificant at 5\%. Standard Errors in Parenthesis

For instruments details see appendix.

This a complex parameter due to its dependence real globalization, competition and complementarity among firms, historical level of inflation, labour sector reforms as elasticity of labour also influences the cost of production, immigration laws as they impact the supply of labor and consequently ability of firms to hire workers at higher or lower wages and above all social norms as participation of women in the labour force can also have influence on this parameter. Each of these demands a specific investigation, which of course is beyond the scope of this study. However, we would like to say that $\mathrm{k}_{\alpha}$ is well estimated, has positive sign for all countries except one, and is in line with the existing literature. The negative sign for Korea is not unusual. For example, Mihailov et al. (2011) finds negative coefficient for Sweden when estimating the full sample (from 1970:1 to 2007:4), for Austria, Sweden and Switzerland for subsample (from 1970:1 to 1986:4) and for Germany, Spain and Netherlands (from 1987:1 to 2007:4). As Korea is relatively open economy, there is possibility that owing to increased openness, domestic factors might have become less important in the determination of inflation. This line of arguments has been put forward by Borio and Filardo (2007) and White (2008), however, as usual, there is another strand of literature like Ball (2006), Mishkin (2007, 2009) and Woodford (2007) that concludes that there is no evidence for a strong effect of globalization in determining domestic inflation. Graphically speaking, if the Phillips curve shifts inward and new equilibrium can take place either at the same level of inflation with lower unemployment (higher output gap) or an economy can strike a point with lower unemployment lower inflation. But what improves the trade-off between inflation and output is an empirical question. Secondly, if productivity is increasing and increase in wages is not catching up the increased productivity, economy might face 
an improved trade-off between inflation and output gap. Nevertheless, in our case we would like to emphasize that the coefficient is insignificant at conventional level of $5 \%$.

Here, we think it is worth mentioning that while estimating we restrict $\alpha$ (import to GDP ratio) so our $\mathrm{k} \alpha$ is not independent of $\alpha$. By imposing this restriction on our Phillips curve we get the value for k $\alpha$ that truly represents the data. We might have estimated both the $k \alpha$ and $\alpha$ but our focus is to get slope parameter that corresponds to the openness index and this has been done by restricting $\alpha$. This makes our Phillips curve different from the one estimated by Mihailov et al. (2011) besides the other difference that we estimate it in the model. Another point we would like to highlight is that literature is skeptic about the empirical significance of forward-looking Phillips curve as documented by Fuhrer (1997) and Jondeau and Le Bihan (2001). However, we find convincing results.

Our next four parameters belong to Taylor rule. These parameters $\rho, \varphi_{\pi}, \varphi_{\mathrm{y}}$ and $\varphi_{\mathrm{e}}$ are smoothing term, response of policy rate to inflation deviation, output gap and exchange rate respectively. Intrinsically, Taylor (1993) did not take into account smoothing policy but researchers like Orphanides (1997) and Clarida, Gali and Gertler (1999) did. Broadly speaking the results are in line with theory. The coefficient attached to the inflation deviation is greater than one and significant for all the countries in the sample. The magnitude of this coefficient greater than 1 is necessary for stability condition. This is called Taylor principle. This ensures that nominal rate is increased so much that it leads to an increase in real interest rate. Since an increase in real interest rate is essential as it provides incentive to economic agents to save. The saving of economic agents at high interest rate ensures effectiveness of demand management policy by the monetary authority. Moreover, the high magnitude reveals that central bank is very aggressive toward inflation movements. It is quite natural in inflation targeting regime.

The central bank response to output gap $\left(\varphi_{\mathrm{y}}\right)$ is also positive and significant at conventional $5 \%$ level of significance. The response to output gap is in line with flexible inflation targeting theory. We would like to mention here that Minella et al. (2002) find a negative relationship between nominal interest rate and output gap for Brazil but their sample range is only from July 1999 to June 2002. For Chile, we have positive but insignificant response of interest rate to output gap. This looks surprising but if we analyze the data more carefully the answer is there. For example, the interest rate remained high for the first half of the sample but of course it has not been the case with inflation deviation. In second half of the sample the interest rate remained quite low relative to the first half. The declining trend in interest rate is quite visible. So keeping the output gap fluctuations more or less constant and declining trend in interest rate make the relationship rather week, and estimated coefficient is insignificant. The coefficients for all other countries have positive sign and are significant. 
The last term in the Taylor rule is nominal exchange rate (an increase in e means depreciation). As we have discussed earlier, we include this term because of the long association of our sample countries with the fixed exchange rate or managed float. Thus we think that the central banks of these countries might be responding to exchange rate movements. The well documented fear of floating thesis leads us to expect positive sign. Historically high pass-through in these countries might still be haunting economic agents. First explaining first, positive and significant response of central bank of Brazil to exchange rate can be explained due to its long association with the fixed exchange rate regime before embracing the IT regime. Furthermore, the reason may be inertia in the thinking of economic agents or the fact that perhaps the central bank of Brazil has not reached a sufficient level of credibility, where a central bank has less incentive to take exchange rate into account. We think that it is may not only be the pass-through, or credibility but the fact that the financial sector stability also demands stability of exchange rate. In addition, according to Correa and Minella (2006) there exists a short-run passthrough of non-linear nature in Brazil, which necessitates response to exchange rate movements.

According to our estimates, Chile also responds to movements in exchange rate. We were less convinced a priori that this would be the result. As Chile is among the pioneers who adopted inflation targeting, we were expecting that exchange rate would be nowhere in reaction function of central bank of Chile. But the situation is reverse. There is international evidence that pass-through has decline due to trade competition in many countries but in case of Chile in a recent study Alvarez et al (2008) finds high and not declining exchange rate pass-through, which would explain our results.

Furthermore, perhaps the valuation channel of external adjustment has also grown in importance that makes exchange rate a variable to be care about.

So far as the response of the Mexican Central bank to exchange rate is concerned, the results are in line with our expectations, as the response to the exchange rate depreciation is positive and significant. The base of our expectation was the study of Hebbel and Werner (2002), which concludes that for Mexico the nominal depreciation has a statistically significant role for inflation expectation. One might argue that the study is a bit old and things might have changed since the Mexico has gone a long way after inflation adoption.

Our next country in the sample, Korea, is different than other countries in the group. As Korea is among developed economies, the usual assumptions of high pass-through, weak financial system do not apply to her. This is evident from our results. The negative sign indicates that central bank of Korea has no particular regard for exchange rate movements. Our conjecture is that low average of inflation rates helped anchoring firms' expectations on one hand, and on the other hand the more open economy of Korea has fostered competition among firms, thus leaving little space for high exchange rate pass-through. 
For Thailand we find significant and positive relationship between nominal exchange rate and nominal interest rate. The results are interesting in the sense that, despite low level of average inflation rates during the sample period, we find significant and positive response to exchange rate. The high import to GDP ratio of Thailand (see Table 4 below) may be an incentive for the monetary authority to take care of exchange rate.

Like Korea, the central bank of Czech Republic also does not respond to exchange rate movements. If we look at the graph we observe appreciating trend of Koruna (see figure 7B in Appendix B). According to Frait (2008), Koruna observed consistent appreciation against US dollar as Czech Republic experienced persistent capital inflows. We find no evidence of response of interest rate to movements in exchange rate.

So Brazil, Chile, Mexico and Thailand clearly respond to exchange rate movements whereas Korea and Czech Republic do not. The study tends to conclude that exchange rate is still an important variable to care about for different reasons so central banks respond to its movements. We would like to reiterate it may not only be the exchange rate pass-through but other factors like financial stability and valuation channel may also be of vital importance. Especially if economies are accumulating reserves, valuation channel becomes also very important.

So far we have estimated and interpreted the parameters like risk aversion, slope of Phillips curve and parameters of the Taylor type rule. But from these parameters we can also recover the underlying structural parameters like, price stickiness. In Table 3 below, we report these parameters and interpret them. Table 3 shows $\lambda$ and the Calvo parameter $\theta$. $\lambda$ is related to $\mathrm{k}_{\alpha, \text { and }} \theta$ is related to $\lambda$ through the following relationship:

$$
\mathrm{k}_{\alpha=\lambda} \lambda\left(\sigma_{\alpha}+\psi\right)
$$

so

$$
\lambda=\mathrm{k}_{\alpha} /\left(\sigma_{\alpha}+\psi\right)
$$

where $\psi$ is elasticity of labour supply. As we know that

$$
\lambda=(1-\theta)(1-\theta \beta) / \theta
$$

We can recover the value of $\theta$ as a function of $\beta$ and $\lambda$. 
Table 3

\begin{tabular}{|l|cc|cc|c|}
\hline & \multicolumn{2}{|c|}{ Estimated } & \multicolumn{2}{|c|}{ Retrieved } & \multirow{2}{*}{ D = 1 ( (1 - $\boldsymbol{\theta})$} \\
\cline { 2 - 5 } & $\boldsymbol{\sigma}_{\boldsymbol{\alpha}}$ & $\mathbf{k}_{\boldsymbol{\alpha}}$ & $\boldsymbol{\lambda}$ & $\boldsymbol{\theta}$ & 20 \\
\hline Brazil & $-38(6.52)$ & $.071(.035)$ & 0.0017 & .95 & 7.69 \\
Chile & $-24(11.10$ & $.55(.10)$ & 0.0190 & .87 & 4.16 \\
Mexico & $-8.35(.95)$ & $.98(.05)$ & 0.0754 & .76 & - \\
Korea & $-11.34(4.86)$ & $-.06(.05)^{*}$ & - & - & 4.76 \\
Thailand & $-1.67(.22)$ & $.41(.03)$ & 0.0615 & .79 & 5.00 \\
Czech & $-6.25(1.88)$ & $.54(.52)$ & 0.0479 & .80 & \\
\hline
\end{tabular}

Note: Elasticity of labour supply( $\psi$ ) assumed 5.

We do not report the value of $\lambda$ and $\theta$ for the Korea because of our poor estimation of $k_{\alpha}$. As it is insignificant so we do not provide the corresponding values for retrieved parameters.

Well, $\lambda$ is retrieved slope parameter of Phillips curve. Our values for $\lambda$ are close to the estimates by Gali et al. (2001), Benigno and Lopez-Salido (2006) and Mihailov et al. (2011). However, a caution is required as the above-mentioned concern advanced economies. The structural parameter $\theta$ measures the degree of price rigidity. Its estimate is quite convincing for Mexico and Thailand as in calibration literature it is assumed to be .75(see, Gali and Monacelli (2005), Eyquem and Kamber (2010)). The higher the value of $\theta$, the higher the degree of price rigidity. In our sample its value ideally should have been lower as these economies experience high inflation relative to advanced countries. But still the values are not unusual. For Brazil, we find a rather high value of $\theta$, which may be due to aggregation problem or problem of measure in the official statistics ${ }^{3}$. What is required is micro investigation in the matter. However, the researchers confront a high value of $\theta$ is not uncommon. Mihailov et al. (2011) find .97 for Netherlands, .96 for Austria and .95 for Switzerland. In the last column we report $\mathrm{D}$, which is the duration of contract i.e. the time for which the price remains unchanged. As this study is using quarterly data so the number correspond to D column should be interpreted as number of quarters for which price remains unchanged.

After the interpretation our structural parameter $\theta$ now we move to Table 4 to interpret another structural parameter $\omega$. This is even a more complex, as it depends on some other structural parameter as given below:

$$
\omega=\sigma \gamma+(1-\alpha)(\sigma \eta-1)
$$

where $\gamma$ measures the substitutability between goods produced in different countries. We set its value equal to 1 as Gali and Monacelli (2005). $\alpha$ is our openness index measured as imports to GDP ratio. $\sigma$

\footnotetext{
${ }^{3}$ The size of underground economy in Brazil was 42.3 percent in 2002/203 Schneider (2004)
} 
is relative risk aversion and $\eta$ measures the substitutability between domestic and foreign goods, from the view-point of domestic consumers. To get the value of $\sigma$ we exploit the following relationship ${ }^{4}$.

$$
\sigma_{\alpha}=\sigma /(1-\alpha)+\alpha \omega
$$

As we have estimated the value of $\sigma_{\alpha}$ in our model, the values of $\omega$ are presented in Table 4 below.

\begin{tabular}{|l|c|c|c|}
\hline \multicolumn{4}{|c|}{ Table 4 } \\
\hline & $\begin{array}{c}\text { Estimated } \\
\boldsymbol{\sigma}_{\boldsymbol{\alpha}}\end{array}$ & $\begin{array}{c}\text { Calibrated } \\
\boldsymbol{\alpha}\end{array}$ & $\begin{array}{c}\text { Retrieved } \\
\boldsymbol{\omega}\end{array}$ \\
\hline Brazil & $-38(6.52)$ & .12 & -7.66 \\
Chile & $-24(11.10$ & .29 & -2.52 \\
Mexico & $-8.35(.95)$ & .28 & -2.96 \\
Korea & $-11.34(4.86)$ & .40 & -1.56 \\
Thailand & $-1.67(.22)$ & .55 & -1.04 \\
Czech & $-6.17(1.88)$ & .38 & -1.77 \\
\hline
\end{tabular}

Note: $\alpha$ is Imports to GDP ratio, $\gamma$ and $\eta$ assumed 1 and 4 respectively.

According to Gali and Monacelli (2005 pp. 722)

"it can be easily checked that contractionary (expansionary) effects dominates whenever $\omega>1(\omega<1)$. In special case considered $\omega=1$, thus implying that a change in world output leaves the terms of trade and domestic output unchanged under DIT policy".

We would like to emphasize that our study does not enjoy the special case and central banks are not under domestic inflation targeting - rather they target CPI. Nevertheless, we think that the line of argument of contraction and expansion of the domestic output as a result of change in world output remains intact. Interestingly, our values of $\omega$ for all the countries are less than 1 , so we tend to conclude that foreign output growth via real appreciation of domestic exchange rate brings expansionary effects for the domestic economy. It could be due to cost channel or the increase in real wealth due to reduction in overall price level. The former increases investment and the latter boosts domestic consumption and so does the aggregate demand.

The results presented are for are quite forceful. The study has tried to bridge the gap between calibrations and to answer a policy-relevant question in a small open economy canonical model

\footnotetext{
${ }^{4}$ We do not report the values of $\sigma$ (Relative Risk Aversion) as it is not well-estimated. It has negative values which imply that agents are risk loving. It is our conjuncture that in developing/ emerging economies consumers faces borrowing constraints and they do not smooth consumption. They increase their consumption when they face positive income shock.
} 
instead of just estimating single Taylor rule equation. In the next section, we conduct a robustness check to further strengthen our results that the central banks in our sample respond to exchange rate.

\subsection{Robustness Check:}

To check robustness we estimate equation (1), (7) and (9). To facilitate the reader we write down these equations

$$
\begin{gathered}
\mathrm{y}_{\mathrm{t}}=\mathrm{E}_{\mathrm{t}} \mathrm{y}_{\mathrm{t}+1}-1 / \sigma_{\alpha}\left(\mathrm{i}_{\mathrm{t}}-\mathrm{E}_{\mathrm{t}}\left(\pi_{\mathrm{t}+1}\right)\right)+\varepsilon^{\mathrm{y}}{ }_{\mathrm{t}} \\
\pi_{\mathrm{t}}=\beta \mathrm{E}_{\mathrm{t}} \pi_{\mathrm{h}, \mathrm{t}+1}+\lambda\left(\sigma_{\alpha}+\psi\right) \mathrm{y}_{\mathrm{t}}+\alpha /(1-\alpha) \Delta \mathrm{q}_{\mathrm{t}}+\varepsilon^{\pi}{ }_{\mathrm{t}} \\
\mathrm{i}_{\mathrm{t}}=\rho \mathrm{i}_{\mathrm{t}-1}+(1-\rho)\left[\varphi_{\pi}\left(\pi_{\mathrm{t}}-\pi^{*}\right)+\varphi_{\mathrm{y}} \mathrm{y}_{\mathrm{t}}+\varphi_{\mathrm{e}}\left(\Delta \mathrm{e}_{\mathrm{t}}\right)\right]+\varepsilon_{\mathrm{t}}^{\mathrm{i}}
\end{gathered}
$$

The difference between this and the above model comes through the middle equation of the model. Here we let the elasticity of labour supply and open economy parameter $\sigma_{\alpha}$ interact to determine the slope of the Phillips curve. Furthermore, simultaneity of $\sigma_{\alpha}$ is quite visible.

We present the results below Table 5. Overall the results almost remain the same. Particularly, when it comes to the Taylor rule - that directly answers our research question - the results remain the same

\begin{tabular}{|c|c|c|c|c|c|c|c|}
\hline & $\sigma_{\alpha}$ & $\lambda$ & $\rho$ & $\varphi_{\pi}$ & $\varphi_{\mathrm{y}}$ & $\varphi_{\mathrm{e}}$ & J (Prob) \\
\hline Brazil & $-39(6.52)$ & $.002(.000)^{* *}$ & $.96(.002)$ & $3.17(.32)$ & $3.61(.44)$ & $.99(.07)$ & $10.27(.92)$ \\
\hline Chile & $-30(14.65)$ & $-.02(.01)$ & $.77(.04)$ & $2.01(.80)$ & $5.93(1.25)$ & $1.00(.21)$ & $16.15(.64)$ \\
\hline Mexico & $-16.93(3.47)$ & $-.06(.02)$ & $.92(.002)$ & $4.74(.19)$ & $1.30(.13)$ & $.13(.05)$ & $9.50(.99)$ \\
\hline Korea & $-10.90(4.57)$ & $.01(.00) *$ & $.96(.003)$ & $7.75(1.27)$ & $1.31(.13)$ & $-1.11(.15)$ & $11.36(.83)$ \\
\hline Thailand & $-1.68(.23)$ & $.04(.00)$ & $.97(.00)$ & $4.11(.80)$ & $.65(.20)$ & $.83(.28)$ & $9.61(.64)$ \\
\hline Czech & $-6.60(2.24)$ & $.16(.12) *$ & $.93(.00)$ & $1.08(.24)$ & $.47(.07)$ & $-.17(.03)$ & $11.99(.74)$ \\
\hline
\end{tabular}
qualitatively.

Table 5: Estimates of NKSOE Model ( $\beta$ and $\alpha$ calibrated)

Note: ** indicates significant at $10 \%$. Standard Errors in Parenthesis. * Insignificant

Elasticity of Labour Supply ( $\Psi$ ) set 3 for Brazil, 5 for Chile, 1 for Mexico \& Korea, 10 for Thailand \& Czech.

For details about instruments see appendix.

The results are broadly in line with the Table 2. The Taylor Principle holds as the response to inflation is greater than 1 . The response to exchange rate is positive and significant for all countries except Korea and Czech Republic.

We would like to highlight here an issue that may arise due to response to exchange rate movements The Time Inconsistency Problem introduced by Kydland and Prescott (1977). The upshot of this problem is Credibility Problem which is related to the lack of commitment and thus inflation bias. 
Simply, in inflation bias central bank tries to increase the output above its natural level thus leading to an increase in inflation ultimately. We investigate how many times the central bank has breached the upper limit of the target set by her and the distribution of output gap. Has the output gap been most of the time near zero or in negative zone or positive one? We think that if actual inflation has remained under the upper target and output gap has been frequently near zero then we tend to rule out inflation bias.

We will present here graphs (figure 2 to 7 below) to know how frequently target inflation was
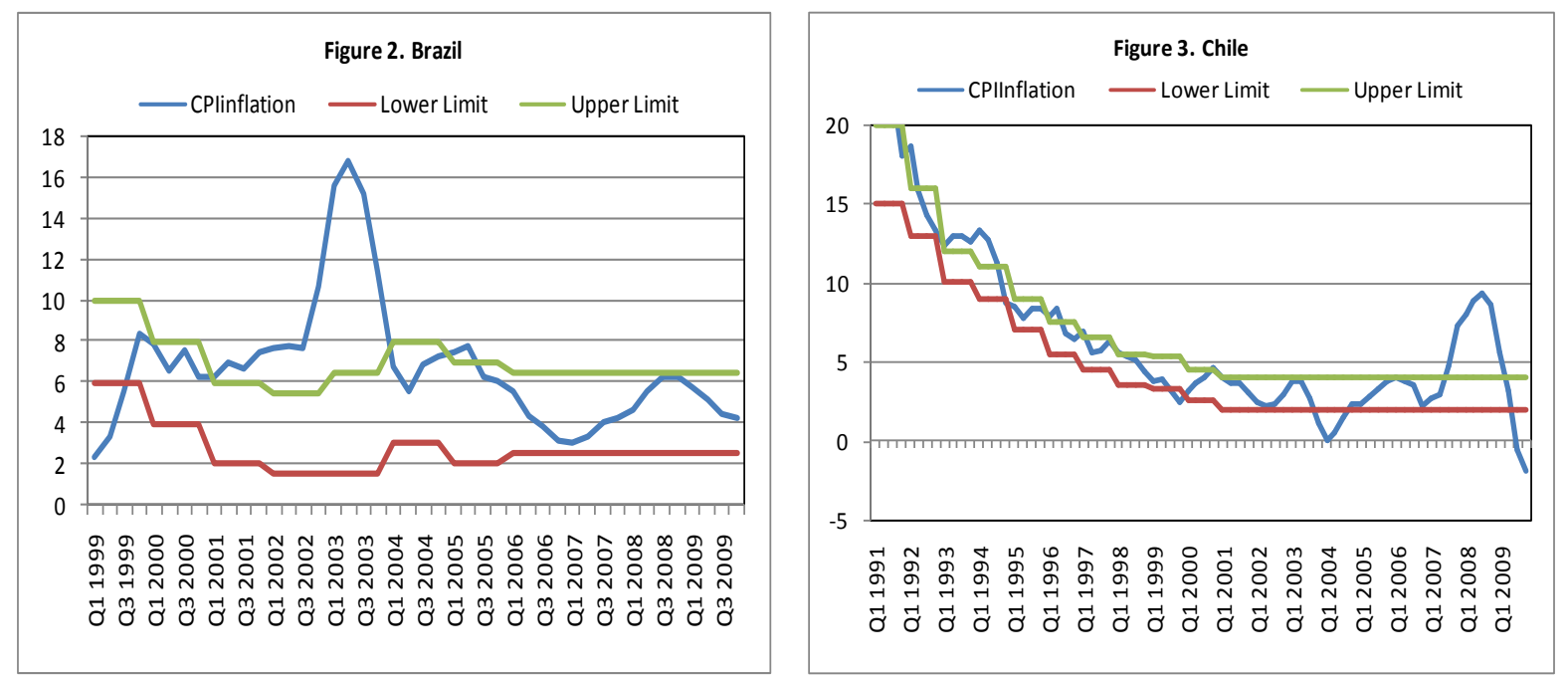

breached. As due to time inconsistency when central bank tries to exploit output higher than natural output this lead to increased inflation in the next period since agents are rational and they cannot be fooled time and again.

In the above diagram it is clear that target has been achieved by the central bank most of the time.
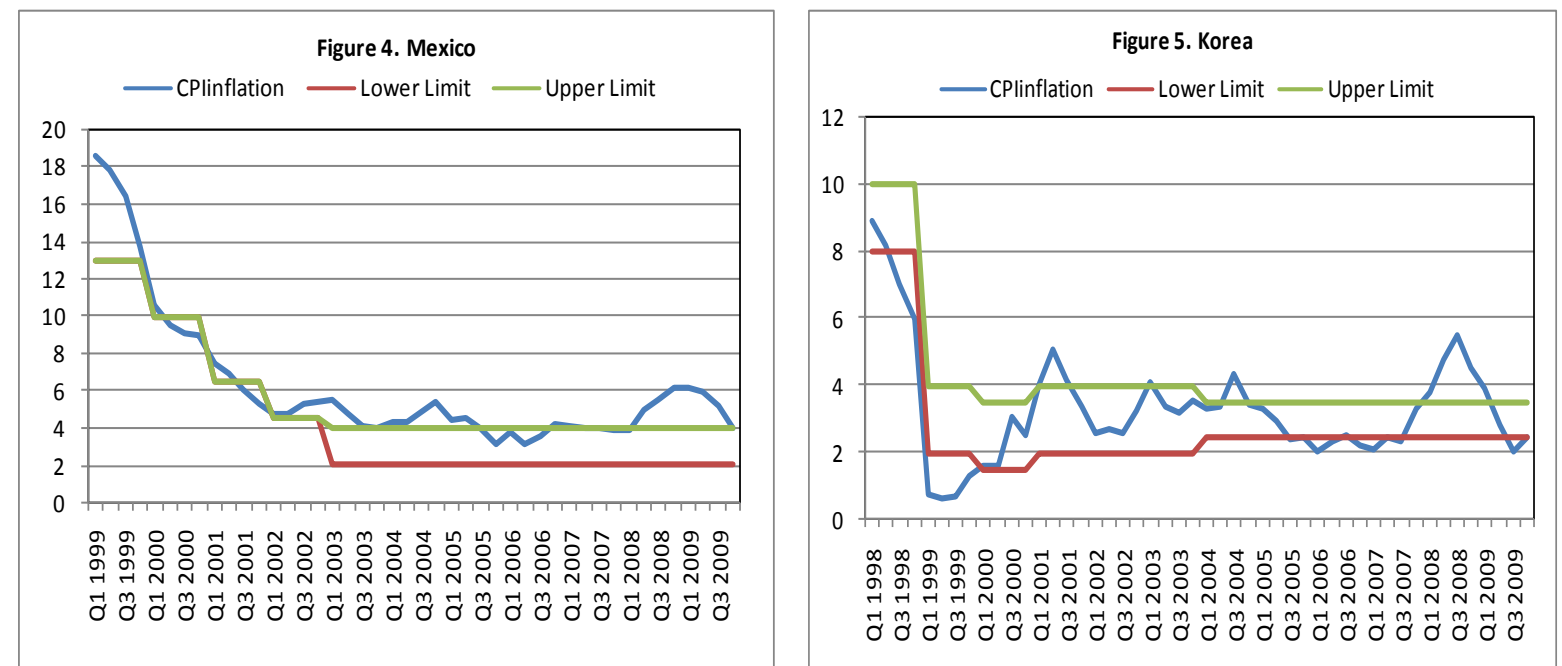

However, in case of Brazil the target was breached around year 2002 due to energy crisis, whereas in case if Chile it has been under control. However, the Chile surpassed its target recently (2007-2008) perhaps due to the financial crisis. 

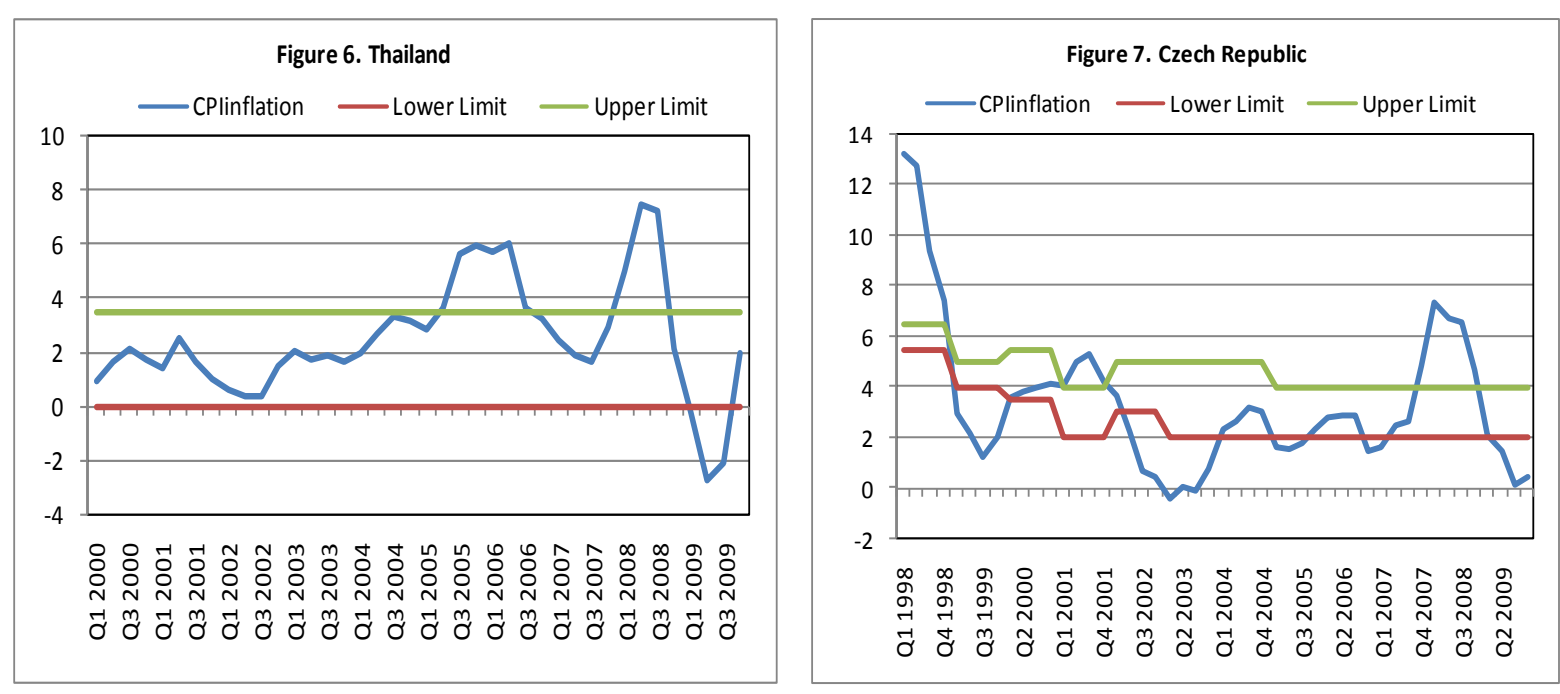

Broadly speaking inflation remained within the limits except for Mexico. In case of Thailand it breached during 2005 and 2006. A common feature of almost all the countries is that the around the subprime crisis inflation increased.

One point comes to mind here. Suppose the target band is $4-6 \%$. Should we assume that zero output gap corresponds to the midpoint i.e. 5 percent inflation. If this is the case the central bank has incentive to increase output gap till the target is within the announced band. What should we call it, inflation bias or not. The central bank will prefer to have zero output gap and 5 percent inflation or positive output gap and 6 percent inflation which is also not breaching the announced band. This question is worth exploring question we think. However, one thing seems certain that, IT regime certainly minimizes inflationary bias as central bank will try hard to keep inflation inside the announced limits. As such, central bank cannot increase the magnitude of output gap to an extent that corresponds to the inflation level outside the upper limit. We think that this is what is called "constrained discretion" in literature (see figures in appendix B).

Moreover, discussing the issue of credibility, we should consider that central banks are under "flexible inflation targeting" regime, they do have regards for output. Under the untoward supply shock, fixing the inflation can lead to higher output volatility. Thus talk about credibility under inflation targeting also demands a fair analysis of shocks that the economy experienced.

Another issue that can lead to credibility problem is frequent changes (each year) in the target set by central bank. However, this issue can be tackled through the credibility supporting actions like; monthly inflation reports, effective communication and disclosing the minutes of the monetary policy committee.

\footnotetext{
${ }^{5}$ Remarks by Governor Ben Bernanke before the money marketeers, New York University, February 2003.
} 
Although most of the time the inflation remained in the announced limits, there has also been periods where the limit was crossed. This phenomenon may lead to credibility problem down the road. The need is to convince the market in such situations through better communication strategy about the factors that led the inflation exceed the upper limit. On the whole, IT anchored the expectations in a good way as countries like Chile, Brazil and Mexico have experienced a history of very high inflation. It seems that these central banks are targeting inflation taking into account exchange rate movements without exceeding the upper limit altogether. The challenge here is; can central banks design a communication strategy that tells clearly that the exchange rate is a variable that central banks respond to and at the same time, avoid the risk of transforming the exchange rate into a nominal anchor that takes precedence over the inflation target as highlighted by Mishkin and Schimdt-Hebbel (2001).

\section{Concluding Remarks:}

The study investigates whether the inflation targeting emerging countries respond to exchange rate movements. Our sample includes 6 emerging economies. The paper uses quarterly data from the adoption of IT regime to the fourth quarter of the year 2009. We base our estimation strategy on a small open economy structural NK canonical model that contains an IS curve, a Phillips curve and a Taylor rule. The study uses multi-equation GMM technique. The motivation behind using GMM is to tackle the inherent endogeneity among variables. The study employees mixed strategy - estimation, calibration and retrieval of parameters thus bridging the gap between estimation and calibration strands of literature. We also do robustness checks to validate our results more forcefully.

Interestingly, we find mixed evidence. Brazil, Chile, Mexico, and Thailand respond to exchange rate movements whereas Korea and Czech Republic do not. On one hand the theory of inflation targeting says that there should be no response to exchange rate. On the other hand, the peculiar conditions of emerging economies remind us that, what is true for advanced economies is not necessarily true for emerging markets. De Gregorio et al. (2005) conclude that the pass-through from exchange rate to inflation has declined, which would make unnecessary for the central bank to respond to exchange rate. But our results are different. Our study shows that central bank of Chile responds to exchange rate. The study of De Gregorio et al. (2005) is a bit old, and one might think that the recent developments in the world economy like more integration, financial crisis and worry about the health of financial system, might have led the central bank of Chile to respond to exchange rate. In case of Brazil too, we find statistically significant response to the exchange rate movements. Possibly, the long association of Brazilian economy with the fixed exchange rate and managed floating exchange rate regime has made the economic agents more considerate toward exchange rate movements and the "inertia" in their thinking towards inflation pressure through the exchange rate pass-through has made it justifiable for the central bank to respond to the exchange rate movements, even in the IT regime. In 
addition, the situation of fiscal dominance in Brazil demands that exchange rate should be taken care of. The point of fiscal dominance has been highlighted in case of Brazil by Blanchard (2004). Similarly, in case of Mexico and Thailand the response to exchange rate is statistically significant.

The study thus concludes that these countries are still under the shadow of "fear of floating". The increasing financial integration has instigated again the debate of "impossible trinity". We call it "compromised impossible trinity" as free float is restricted by response to exchange rate movement (and intervention in the foreign exchange market) and capital movement is also restricted in some countries. For instance, Brazil imposed tax on capital inflows. So the study concludes that these countries have not yet reached the stage where the central bank assigns statistically insignificant value to exchange rate in its reaction function.

However, Czech Republic and Korea do not respond to exchange rate movements. Korea is an advanced economy and thus differs from the so-called emerging or developing economies. The response to Czech Republic is somewhat unusual.

On the intellectual front, the study points to the necessity to formulate a theory that assigns due weight to exchange rate in inflation targeting. On the policy side, the challenge is to design an effective communication strategy that prevents exchange rate to become a nominal anchor as underscored by Mishkin and Schimdt-Hebbel (2001). 


\section{References:}

Aghion, P., Bacchetta, P. \& Banerjee, A. (2001), "Currency Crisis and Monetary Policy in an economy with credit constraints", European Economic Review 45(7), 1121-1150.

Aizenman, H., Hutchison, M. \& Noy, I. (2008), "Inflation targeting and real exchange rates in emerging markets", NBER working paper 14561.

Alvarez, R. Jaramillo, P. \& Selaive, J. (2008), Exchange Rate Passthrough into Import Prices : The Case of Chile » Bank of Chile, Working paper 465.

Ball, L. (2000), "Policy rules and external shocks" Central Bank of Chile, Working paper 82.

Ball, L. (2006), “Has Globalization Changed Inflation?”, NBER Working Paper No. 12687.

Batini, N., Harrison, R., \& Millard, S. P. (2003) "Monetary policy rules for an open economy", Journal of Economic Dynamics and Control, 27, 2059-2094.

Benigno, P \& L-Salido, J. D., "Inflation persistence and Optimal monetary Policy in the Euro Area”, Journal of Money, Credit and Banking, Vol. 38, No. 3, pp. 587 - 614.

Bilbiie, F.O. (2008), "Limited Asset Markets Participation, Monetary Policy and (Inverted) Aggregate Demand Logic", Journal of Economic Theory 140, pp 162-196.

Blanchard, O. (2004), "Fiscal Dominance and Inflation Targeting: Lessons from Brazil", NBER Working Paper 10389.

Borio, C. \& Filardo, A. (2007), "Globalization and inflation: New Cross-country evidence on the global determinants of domestic inflation”, BIS Working Paper No. 227.

Calvo, G. A. (1983), "Staggered Prices in a Utility-Maximizing Framework", Journal of Monetary Economics, 12, pp 383-398.

Calvo, G. A., Reinhart, C. M. \& Végh, C.A. (1995), “Targeting the real exchange rate: theory and evidence", Journal of development economics, Vol. (47), 97-133.

Calvo, G. A. \& Reinhart, C. M. (2000), "Fear of floating”, NBER Working Paper No. 7993.

Calvo, G. A. \& Reinhart, C. M. (2002), "Fear of floating", The quarterly journal of economics, Vol. (CXVII), 379-408.

Carstens, A. G. \& Werner, A. M. (1999), “Mexico's monetary policy framework under a floating exchange rate regime", Central Bank of Mexico, Research Paper No. 9905. (May).

Cavoli, T. (2009), "Is fear of floating justifies? The East Asia experience", Journal of Policy Modeling, 31, 1-16. 
Creel, J. \& Levasseur, S. (2004), "How would a fixed-exchange-rate regime fit the transition economies? The case of the Czech Republic, Hungary and Poland, Central Bank of Czech Republic, Special Issue, April 2004.

Chadha, J. S. \& Dimsdale, N. H. (1999), “A Long View of Real Rates", Oxford Review of Economic Policy, Vol. 15 No. 2. pp 17-45.

Clarida, R., Gali, J. \& Gertler, M., (1998), «Monetary Policy Rules in Practice : Some International Evidence », European Economic Review, 42 pp 1033-1067.

Correa, A. S. \& Minella, A. (2006), "Nonlinear Mechanism of the Exchange Rate PassTheorugh: A Phillips Curve Model with Threshold for Brazil", Central Bank of Brazil Working Paper No. 122.

Dees et al. (2008), "Identification of new Keynesian Phillips curves from a global perspectives", CESifo, Working Paper No. 2219.

De Gregorio, J., Tokman, A. \& Valdés, R. (2005), "Flexible Exchange Rate with Inflation targeting in Chile: Experience and Issues", Inter-American development Bank WP No. 540.

De Paoli, B. (2006), "Monetary Policy and Welfare in a small open economy", CEP Discussion Paper No. 639.

Dooley, M., Dorbusch, R. \& Park, Y. C. (2002), “A Framework for Exchange Rate Policy in Korea”, Korean Institute for International Economic Policy, Working Paper No. 2.

Edwards, S. (2006), "The relationship between exchange rate and inflation targeting revisited”, NBER Working Paper No. 12163.

Eyquem, A. \& Kamber, G. (2010), “Internationalized Production in a Small Open Economy”, Reserve Bank of New Zealand, Discussion Paper No. 4 (August).

Favero, C. A. (2005), “Consumption, Wealth, the Elasticity of Intertemporal Substitution and Long-Run Stock Market returns”. http://www.csef.it/wise3/Favero.pdf

Frait, J. (2008), "Financial Market turbulence", Speech at OECD Forum Climate Change, Growth, Stability, 3-4 June 2008, Paris. http://www.oecd.org/dataoecd/2/6/40777356.pdf

Fuhrer, J.C. (1997), "The (Un)Importance of Forward-Looking Behaviour in Price Specifications", Journal of Money, Credit and Banking, Vol. 29, No. 3 pp. 338-350.

Gali, J. (2008), "Monetary Policy, Inflation, and the Business Cycle An Introduction to the New Keynesian Framework” Princeton University Press.

Gali, J. \& Gertler, G. (1999), "Inflation Dynamics: A Structural Econometric Analysis", Journal of Monetary Economics, 44, pp. 195-222. 
Gali, J. \& Monacelli, T. (2005), "Monetary Policy and Exchange Rate Volatility in a Small Open Economy”, The Review of Economic Studies, Vol. 72, No. 3, pp. 707-734.

Gali, J., Gertler, M. \& Lopez-Salodi, J. D. (2001), «European Inflation Dynamics », European Economic Review, 45, pp.1237-1270.

Gallant, A. R. \& Tauchen, G. (1996), "Which Moments to Match?” Econometric Theory, Vol. 12, No. 4, pp. 657-681.

Hayashi, F. (2000), “Econometrics”, Princeton University Press.

Hebbel, K. \& Tapia, M. (2002), "Inflation targeting in Chile", The north American Journal of economics and finance, (13) 125-146.

Hebbel, K.S. \& Werner, A. (2002), "Inflation Targeting in Brazil, Chile and Mexico: Performance, credibility and the exchange rate" Economia, spring.

Jondeau, E. \& Le Bihan, H. (2001), “Testing for Forward-Looking Phillips Curve. Additional Evidence from European and US Data" NER No. 86, Banque De France.

Kaminsky, G. L. \& Reinhart, C. M. (1999), "The twin crisis: the causes of banking and balance-of -payments problems", The American Economic Review, June. 473-500.

Kydland, F. and Prescott, E. (1977), "Rules rather than Discretion: The inconsistency of optimal plans", Journal of Political Economy, 85, 473-490.

Lane, P. R. \& Milesi-Ferretti, G. M. (2006), "The External Wealth of Nations Mark II: Revised and Extended Estimates of Foreign Assets and Liabilities, 1970-2004", IMF Working Paper No. 69.

Mihailov. A., Rumler, F \& Scharler, J. (2011), "The Small Open Economy New Keynesian Phillips Curve: Empirical Evidence and Implied Inflation Dynamics", Open Economy Review (23), pp. $317-337$.

Minella, A., De Freitas, P. S., Goldfajn, I. \& Muinhos, M. K. (2002), "Inflation Targeting in Brazil: Lessons and Challengees”, Central Bank of Brazil, Working Paper No. 53.

Mishkin, F. S. \& Schmidt-Hebbel, K. (2001), "One decade of inflation targeting in the world: What do we know and what do we need to know?", NBER Working Paper 8397.

Mishkin, F. S. (2007), “Inflation dynamics”, International Finance, 10 (3), 317-334.

Mishkin, F. S. (2008), “Globalization, Macroeconomic Performance and Monetary Policy”, NBER Working Paper No. 13948.

Mohanty, M \& Klau, M. (2004), "Monetary Policy rules in emerging market economies: issues and evidence", BIS Working Paper No.149. 
Neiss, K.S. \& Nelson, E. (2001), “The real interest rate gap an inflation indicator”, Bank of England, Working Paper No. 130.

Orphanides, A. (2001), "Monetary policy Rules Based on real time data", The American Economic review, Vol. 91. No. 4.

Osawa, N. (2006), “ Monetary policy responses to the exchange rate: Empirical evidence from three east asian inflation targeting countries", Bank of Japan, Working Paper Series (September).

Parrado, E. (2004), "Inflation targeting and Exchange Rate rules in an Open Economy", IMF working Paper No. 21.

Svensson, E. O. Lars. (1997), "Inflation forecast targeting: Implementing and monitoring inflation targets", European Economic Review (41), 1111-1146.

Svensson, E. O. Lars. (1999), "Inflation Targeting as a Monetary policy rule", Journal of Monetary Economics (43), 607-654.me

Tauchen, G. (1986), "Statistical Properties of Generalized Method-of-Moments of Structural parameters Obtained from Financial Data", Journal of Business and Economic Statistics, Vol. 4, No. 4, pp. 397-416.

Taylor, J. B. (1980), “Aggregate Dynamics and Staggered Contracts", The Journal of Political Economy, Vol. 88, No. 1, pp. 1-23.

Verbeek, M. (2004), “A guide to modern econometrics”, John Wiley \& Sons, Ltd.

White, W., R. (2008), "Globalization and the determinants of Domestic Inflation", BIS Working Paper No. 250.

Woodford, M. (2003), “Interest and Prices: Foundations of a Theory of a Monetary Policy”, Princeton University Press.

Woodford, M. (2003), "Globalization and Monetary Control”, NBER working Paper no. 13329. 


\section{Appendix A}

Table $1 \mathrm{~A}$

\begin{tabular}{|c|c|c|c|}
\hline \multicolumn{4}{|c|}{ Key Facts of Sample Economies } \\
\hline & $\begin{array}{c}\text { Year Started } \\
\text { Inflation Targeting }\end{array}$ & $\begin{array}{c}\text { Targeted Inflation } \\
\text { Concept }\end{array}$ & $\begin{array}{l}\text { Policy/Official } \\
\text { Interest Rate }\end{array}$ \\
\hline Brazil & 1999 & CPI & SELIC O/N \\
\hline Chile & 1991 & CPI & O/N Discount \\
\hline Mexico & 1999 & CPI & 91 days Cetes \\
\hline Korea & 1998 & Core CPI & $\mathrm{O} / \mathrm{N}$ Call \\
\hline Thailand & 2000 & Core CPI & 14-day Repo \\
\hline Czech Republic & 1998 & CPI & 2-week Repo \\
\hline
\end{tabular}

Source: Mishkin and Schmidt-Hebbel (2001); Ho and McCualey (2003)

\begin{tabular}{|c|c|c|c|c|c|c|}
\hline \multicolumn{7}{|c|}{ Table 2 A } \\
\hline \multicolumn{7}{|c|}{ Descriptive Statistics of Key Variables } \\
\hline \multicolumn{7}{|c|}{ Percent } \\
\hline Variable & Brazil & Chile & Mexico & Korea & Thailand & Czech Republic \\
\hline Inflation & $\begin{array}{c}6.79 \\
(2.30-16.85)\end{array}$ & $\begin{array}{c}6.95 \\
(.005-24.08)\end{array}$ & $\begin{array}{c}6.34 \\
(3.09-18.60)\end{array}$ & $\begin{array}{c}3.29 \\
(.59-8.93)\end{array}$ & $\begin{array}{c}2.76 \\
(-2.79-10.29)\end{array}$ & $\begin{array}{c}3.42 \\
(-.38-13.26)\end{array}$ \\
\hline Interest Rate & $\begin{array}{c}17.16 \\
(8.65-37.80)\end{array}$ & $\begin{array}{c}10.93 \\
(.48-36.86)\end{array}$ & $\begin{array}{c}10.84 \\
(5.10-31.62)\end{array}$ & $\begin{array}{c}5.06 \\
(1.87-23.92)\end{array}$ & $\begin{array}{c}3.26 \\
(1.01-20.64)\end{array}$ & $\begin{array}{c}4.37 \\
(1.54-15.81)\end{array}$ \\
\hline Exchange Rate & $\begin{array}{c}4.55 \\
(-29.44-48.28)\end{array}$ & $\begin{array}{c}2.99 \\
(-20.56-30.80)\end{array}$ & $\begin{array}{c}2.52 \\
(-9.40-29.26)\end{array}$ & $\begin{array}{c}1.39 \\
(-34.20-43.56)\end{array}$ & $\begin{array}{c}.42 \\
(-25.28-49.51)\end{array}$ & $\begin{array}{c}-4.56 \\
(-33.83-24.95)\end{array}$ \\
\hline Output Gap & $\begin{array}{c}1.90 \mathrm{E}-11 \\
(-6.27-5.34)\end{array}$ & $\begin{array}{c}.14 \\
(-7.75-5.96)\end{array}$ & $\begin{array}{c}.23 \\
(-8.16-5.36)\end{array}$ & $\begin{array}{c}-.72 \\
(7.88-14.46)\end{array}$ & $\begin{array}{c}-.61 \\
(-9.33-6.68)\end{array}$ & $\begin{array}{c}3.19 \mathrm{E}-11 \\
(-6.20-3.78)\end{array}$ \\
\hline Real Interets Rate & $\begin{array}{c}9.38 \\
(3.07-30.09)\end{array}$ & $\begin{array}{c}3.65 \\
(-9.98-24.23)\end{array}$ & $\begin{array}{c}2.18 \\
(-12.32-15.13)\end{array}$ & $\begin{array}{c}2.46 \\
(-4.46-17.21)\end{array}$ & $\begin{array}{c}.70 \\
(-3.41-9.35)\end{array}$ & $\begin{array}{c}1.37 \\
(-4.15-6.18)\end{array}$ \\
\hline
\end{tabular}




\begin{tabular}{|c|c|c|c|c|c|}
\hline \multicolumn{6}{|c|}{ Table 3 A: Brazil } \\
\hline \multicolumn{6}{|c|}{ Covariance Matrix } \\
\hline & Inflation & Interest Rate & Exchange Rate & Output Gap & Real Interets Rate \\
\hline Inflation & 9,69 & - & - & - & - \\
\hline Interest Rate & 6,49 & 28,49 & - & - & - \\
\hline Exchange Rate & 4,20 & 51,14 & 510,57 & - & - \\
\hline Output Gap & $-1,34$ & $-3,62$ & $-5,19$ & 5,75 & - \\
\hline Real Interets Rate & 0,58 & 19,90 & 27,63 & $-3,53$ & 20,60 \\
\hline \multicolumn{6}{|c|}{ Correlation Matrix } \\
\hline & Inflation & Interest Rate & Exchange Rate & Output Gap & Real Interets Rate \\
\hline Inflation & 1,00 & - & - & - & - \\
\hline Interest Rate & 0,39 & 1,00 & - & - & - \\
\hline Exchange Rate & 0,06 & 0,42 & 1,00 & - & - \\
\hline Output Gap & $-0,18$ & $-0,28$ & $-0,10$ & 1,00 & - \\
\hline Real Interets Rate & 0,04 & 0,82 & 0,27 & $-0,32$ & 1,00 \\
\hline
\end{tabular}

\begin{tabular}{|c|c|c|c|c|c|}
\hline \multicolumn{6}{|c|}{ Table 4 A: Chile } \\
\hline \multicolumn{6}{|c|}{ Covariance Matrix } \\
\hline & Inflation & Interest Rate & Exchange Rate & Output Gap & Real Interets Rate \\
\hline Inflation & 29,10 & - & - & - & - \\
\hline Interest Rate & 37,71 & 77,07 & - & - & - \\
\hline Exchange Rate & 16,19 & 24,62 & 86,42 & - & - \\
\hline Output Gap & $-0,55$ & $-4,31$ & $-3,32$ & 8,02 & - \\
\hline Real Interets Rate & 18,16 & 51,54 & 23,33 & $-2,58$ & 53,37 \\
\hline \multicolumn{6}{|c|}{ Correlation Matrix } \\
\hline & Inflation & Interest Rate & Exchange Rate & Output Gap & Real Interets Rate \\
\hline Inflation & 1,00 & - & - & - & - \\
\hline Interest Rate & 0,80 & 1,00 & - & - & - \\
\hline Exchange Rate & 0,32 & 0,30 & 1,00 & - & - \\
\hline Output Gap & $-0,04$ & $-0,17$ & $-0,13$ & 1,00 & - \\
\hline Real Interets Rate & 0,46 & 0,80 & 0,34 & $-0,12$ & 1,00 \\
\hline
\end{tabular}

\begin{tabular}{|c|c|c|c|c|c|}
\hline \multicolumn{6}{|c|}{ Table 5 A: Mexico } \\
\hline \multicolumn{6}{|c|}{ Covariance Matrix } \\
\hline & Inflation & Interest Rate & Exchange Rate & Output Gap & Real Interets Rate \\
\hline Inflation & 14,70 & - & - & - & - \\
\hline Interest Rate & 20,24 & 31,57 & - & - & - \\
\hline Exchange Rate & 0,42 & $-4,00$ & 61,31 & - & - \\
\hline Output Gap & 3,37 & 5,95 & $-5,01$ & 9,98 & - \\
\hline Real Interets Rate & 12,00 & 22,45 & $-13,49$ & 5,83 & 35,21 \\
\hline \multicolumn{6}{|c|}{ Correlation Matrix } \\
\hline & Inflation & Interest Rate & Exchange Rate & Output Gap & Real Interets Rate \\
\hline Inflation & 1,00 & - & - & - & - \\
\hline Interest Rate & 0,94 & 1,00 & - & - & - \\
\hline Exchange Rate & 0,01 & $-0,09$ & 1,00 & - & - \\
\hline Output Gap & 0,28 & 0,34 & $-0,20$ & 1,00 & - \\
\hline Real Interets Rate & 0,53 & 0,67 & $-0,29$ & 0,31 & 1,00 \\
\hline
\end{tabular}




\begin{tabular}{|c|c|c|c|c|c|}
\hline \multicolumn{6}{|c|}{ Table 6 A: Korea } \\
\hline \multicolumn{6}{|c|}{ Covariance Matrix } \\
\hline & Inflation & Interest Rate & Exchange Rate & Output Gap & Real Interets Rate \\
\hline Inflation & 2,86 & - & - & - & - \\
\hline Interest Rate & 4,38 & 13,41 & - & - & - \\
\hline Exchange Rate & 19,14 & 32,29 & 271,16 & - & - \\
\hline Output Gap & $-2,51$ & $-8,32$ & $-31,86$ & 24,57 & - \\
\hline Real Interets Rate & 3,81 & 11,97 & 18,68 & $-7,51$ & 15,64 \\
\hline \multicolumn{6}{|c|}{ Correlation Matrox } \\
\hline & Inflation & Interest Rate & Exchange Rate & Output Gap & Real Interets Rate \\
\hline Inflation & 1,00 & - & - & - & - \\
\hline Interest Rate & 0,71 & 1,00 & - & - & - \\
\hline Exchange Rate & 0,69 & 0,54 & 1,00 & - & - \\
\hline Output Gap & $-0,30$ & $-0,46$ & $-0,39$ & 1,00 & - \\
\hline Real Interets Rate & 0,57 & 0,83 & 0,29 & $-0,38$ & 1,00 \\
\hline
\end{tabular}

\begin{tabular}{|l|ccccc|}
\hline \multicolumn{7}{|c|}{ Table 7 A: Thailand } \\
\hline \multicolumn{7}{|c|}{ Covariance Matrix } \\
\hline & Inflation & Interest Rate & Exchange Rate & Output Gap & Real Interets Rate \\
\hline Inflation & 3,49 & - & - & - & - \\
Interest Rate & 1,13 & 1,34 & - & - & - \\
Exchange Rate & $-1,42$ & $-3,10$ & 50,69 & - & - \\
Output Gap & 0,90 & 0,66 & $-5,31$ & 11,19 & - \\
Real Interets Rate & $-1,27$ & 0,48 & $-3,09$ & $-0,71$ & 3,02 \\
\hline \multicolumn{7}{|c|}{ Correlation Matrox } & & \\
\hline & \multicolumn{7}{c|}{ Inflation } & Interest Rate & Exchange Rate & Output Gap & Real Interets Rate \\
\hline Inflation & 1,00 & - & - & - & - \\
Interest Rate & 0,52 & 1,00 & - & - & - \\
Exchange Rate & $-0,11$ & $-0,38$ & 1,00 & - & - \\
Output Gap & 0,14 & 0,17 & $-0,22$ & 1,00 & - \\
Real Interets Rate & $-0,39$ & 0,24 & $-0,25$ & $-0,12$ & 1,00 \\
\hline
\end{tabular}

\begin{tabular}{|c|c|c|c|c|c|}
\hline \multicolumn{6}{|c|}{ Table 8 A: Czech Republic } \\
\hline \multicolumn{6}{|c|}{ Covariance Matrix } \\
\hline & Inflation & Interest Rate & Exchange Rate & Output Gap & Real Interets Rate \\
\hline Inflation & 8,42 & - & - & - & - \\
\hline Interest Rate & 7,97 & 10,70 & - & - & - \\
\hline Exchange Rate & 2,61 & 10,05 & 162,54 & - & - \\
\hline Output Gap & 0,27 & 1,10 & $-3,91$ & 7,74 & - \\
\hline Real Interets Rate & 2,34 & 4,16 & 4,17 & 0,84 & 5,16 \\
\hline \multicolumn{6}{|c|}{ Correlation Matrox } \\
\hline & Inflation & Interest Rate & Exchange Rate & Output Gap & Real Interets Rate \\
\hline Inflation & 1,00 & - & - & - & - \\
\hline Interest Rate & 0,84 & 1,00 & - & - & - \\
\hline Exchange Rate & 0,07 & 0,24 & - & - & - \\
\hline Output Gap & 0,03 & 0,12 & $-0,11$ & 1,00 & - \\
\hline Real Interets Rate & 0,35 & 0,56 & 0,14 & 0,13 & 1,00 \\
\hline
\end{tabular}




\begin{tabular}{|c|c|c|c|c|c|c|}
\hline \multicolumn{7}{|c|}{ Table 9 A: Stationarity Tests } \\
\hline \multicolumn{3}{|c|}{ Brazil } & \multicolumn{2}{|c|}{ Chile } & \multicolumn{2}{|c|}{ Mexico } \\
\hline Variable & ADF & KPSS (Andrew) & ADF & KPSS (Andrew) & ADF & KPSS (Andrew) \\
\hline output gap & $-3,90$ & 0,05 & $-3,36$ & 0,13 & $-3,05 * *$ & 0,13 \\
\hline Real interest rate & $-10,01$ & 0,14 & -8,28@ & 0,13 & -4,51@ & 0,42 \\
\hline Exchange Rate & $-3,92^{*}$ & 0,37 & $-3,40$ & 0,24 & -6,18@ & 0,05 \\
\hline Inflation & $-3,73^{*}$ & 0,18 & $-3,80$ & 0,34 & $-4,88$ & 0,35 \\
\hline Nominal Interest Rate & $-3,80 @$ & 0,31 & $-2,92$ & 0,06@ & $-3,86 @$ & 0,40 \\
\hline Inflation Deviation & $-5,70$ & 0,30 & $-5,49 *$ &, $14^{*}$ & $-2,52 * *$ & 0,28 \\
\hline Real Exchange Rate & $-2,13 * *$ & 0,43 & $-2,3 * *$ & 0,17 & $-2,32 * *$ & 0,29 \\
\hline
\end{tabular}

For KPSS we use Bartlett Kernal and Andrews Bandwidth. For ADF we use Schwartz Information criterion All the result have been reporteda t conventional $5 \%$ significant level.

* stationary with trend and intercept

** stationary without trend and intercept

@ stationary at first difference

\begin{tabular}{|c|c|c|c|c|c|c|}
\hline \multicolumn{7}{|c|}{ Table 10 A: Stationarity Tests } \\
\hline & \multicolumn{2}{|c|}{ Korea } & \multicolumn{2}{|c|}{ Thailand } & \multicolumn{2}{|c|}{ Czech Republic } \\
\hline Variable & ADF & KPSS (Andrew) & ADF & KPSS (Andrew) & ADF & KPSS (Andrew) \\
\hline output gap & $-3,51$ & 0,06 & $-2,66 * *$ & 0,27 & -4,11@ & 0,4 \\
\hline Real interest rate & $-3,47$ & 0,13 & $-3,50$ & 0,22 & $-2,25 * *$ & 0,38 \\
\hline Exchange Rate & $-3,95$ & 0,14 & $-2,43 * *$ & 0,37 & $-4,05$ & 0,21 \\
\hline Inflation & $-6,70$ & 0,14 & $-3,29$ & 0,07 & -6,92@ & 0,29 \\
\hline Nominal Interest Rate & $-3,08$ & 0,44 & $-3,81 @$ & 0,27 & $-6,94$ & 0,38 \\
\hline Inflation Deviation & $-4,85$ & 0,13 & $-5,49$ & 0,31 & $-4,23$ & 0,24 \\
\hline Real Exchange Rate & $-4,25$ & $0,13 * *$ & $-5,81$ & 0,37 & $-5,66$ & 0,07 \\
\hline
\end{tabular}

For KPSS we use Bartlett Kernal and Andrews Bandwidth. For ADF we use Schwartz Information criterion

All the result have been reporteda t conventional $5 \%$ significant level.

* stationary with trend and intercept

** stationary without trend and intercept

@ stationary at first difference

\section{Appendix B}

\section{Relationship between Inflation and Output Gap}

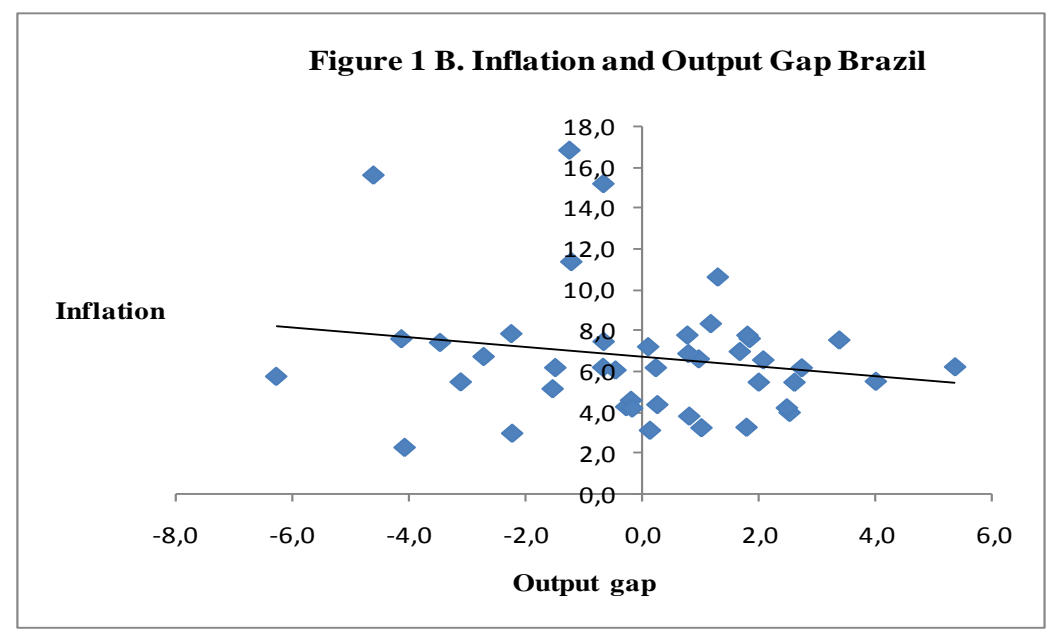



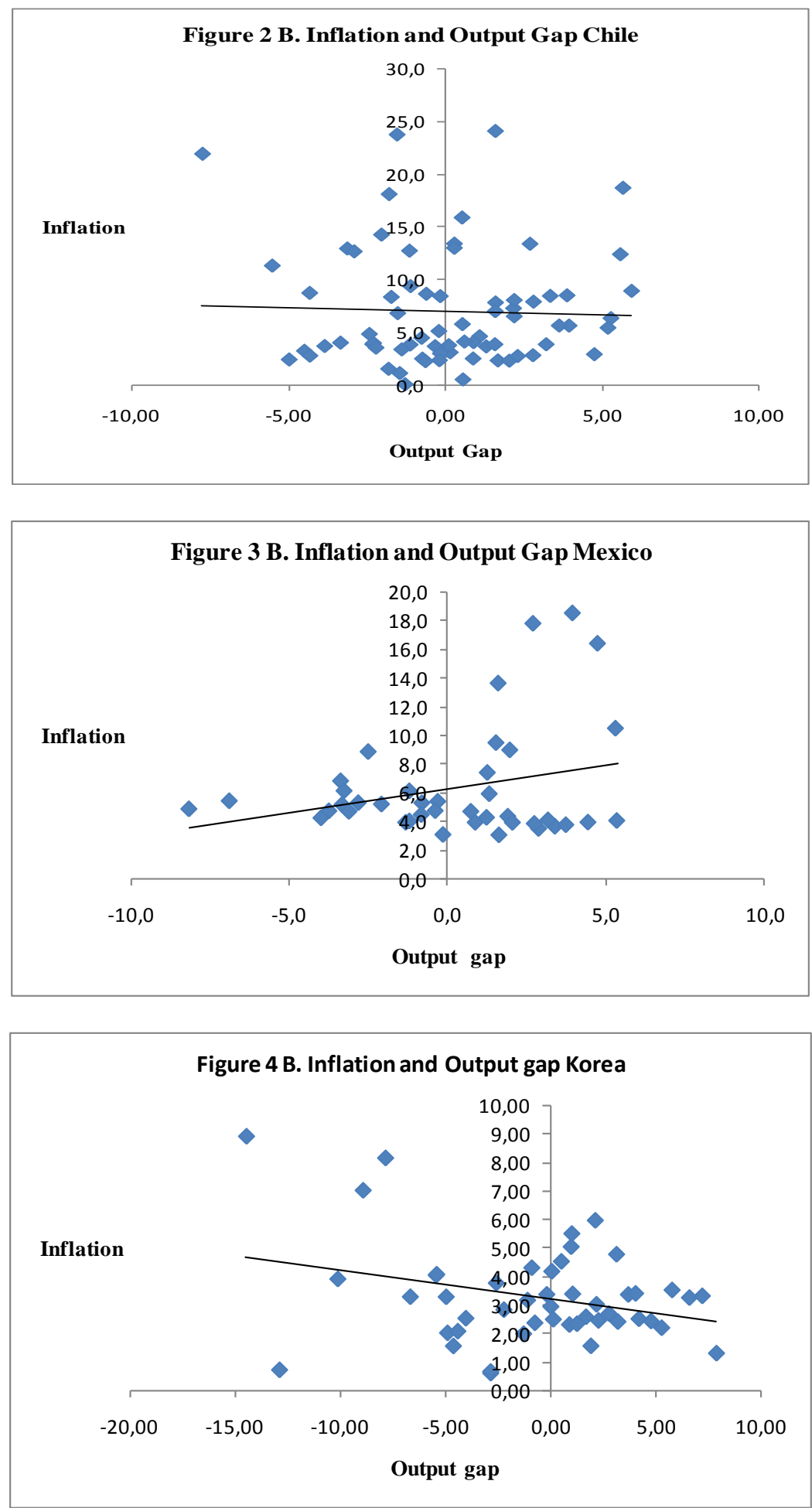

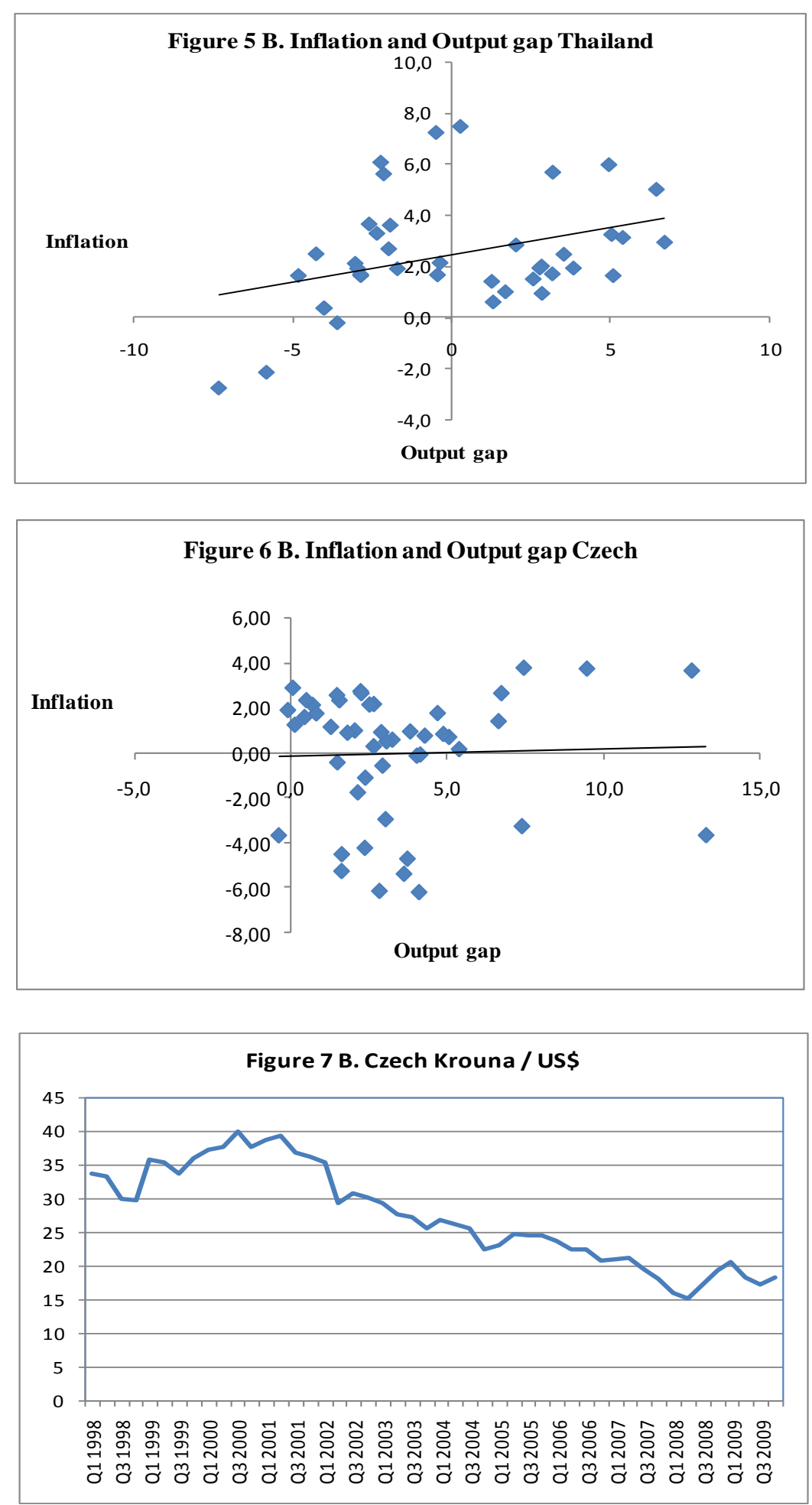


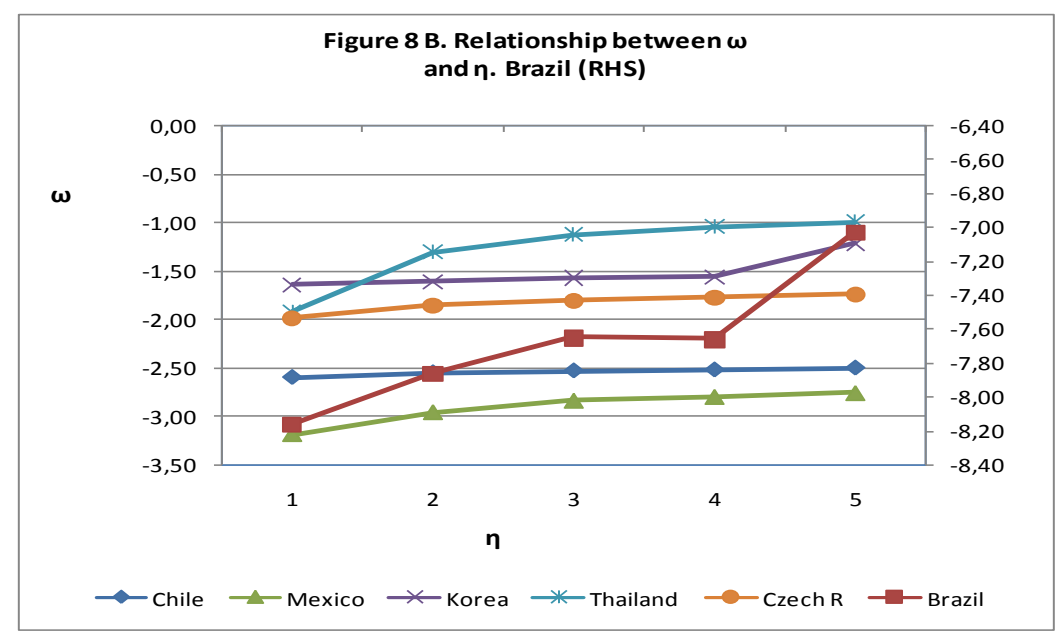

\section{List of Instruments Used in Regression:}

\section{In Table 2:}

Brazil:

IS Equation: output gap lag 1 to 4 , real interest rate lag 1 to 4 , exchange rate lag 1 to 4 .

Phillips Curve: inflation 1 to 4, output gap 1 to 4 , real exchange rate 1 to 4 .

Taylor rule: interest rate 1 to 4 , inflation deviation 1 to 4, output gap 1 to 4, Exchange rate 1 to 4 .

Chile:

IS Equation: output gap lag 1 to 4 , real interest rate lag 1 to 4 , real exchange rate lag 1 to 4 .

Phillips Curve: inflation 1 to 4 , output gap 1 to 4 , real exchange rate 1 to 4 .

Taylor rule: interest rate 1 to 2 , output gap 1 to 3 , real exchange rate 1 to 3 .

Mexico:

IS Equation: output gap lag 1 to 4, real interest rate lag 1 to 4 , exchange rate lag 1 to 4 .

Phillips Curve: inflation 1 to 4 , output gap 1 to 4 , real exchange rate 1 to 4 .

Taylor rule: interest rate 1 to 4 , output gap 1 to 4 , exchange rate 1 to 4 , inflation deviation 1 to 4 .

Korea:

IS Equation: output gap lag 1 to 4 , real interest rate lag 1 to 4 .

Phillips Curve: inflation 1 to 4, output gap 1 to 4 , real exchange rate 1 to 4 .

Taylor rule: interest rate 1 to 4 , output gap 1 to 4 , real exchange rate 1 to 4 , inflation deviation 1 to 4 .

Thailand:

IS Equation: output gap lag 1 to 4, real interest rate lag 1 to 4 , real exchange rate 1 to 4 lag. 
Phillips Curve: inflation 1 to 2, output gap 1 to 2 , real exchange rate 1 to 2 .

Taylor rule: interest rate 2 to 4 , output gap 1 to 2 , exchange rate 1 to 2 , inflation deviation 1 to 2 .

Czech republic:

IS Equation: output gap lag 1 to 2, real interest rate lag 1 to 2, exchange rate 1 to 4 lag.

Phillips Curve: inflation 1 to 2, output gap 1 to 2 , real exchange rate 1 to 6 .

Taylor rule: interest rate 1 to 2, output gap 1 to 4 , exchange rate 1 to 2, inflation deviation 1 to 2 .

\section{In Table 5:}

Brazil: same as in table 2.

Chile:IS Equation: same as in table 2

Phillips Curve: same as in table 2.

Taylor rule: interest rate 1 to 2 , output gap 1 to 3 , real exchange rate 1 to 3 .

Mexico: same as in table 2 except real rate in IS Equation.

Korea: same as in table 2

Thailand: same as in table 2, except real interest rate 1 to 2 instead of nominal interest rate.

Czech republic: same as in table 2 except in Phillips curve inflation and real exchange rate lag 1 to 6. 